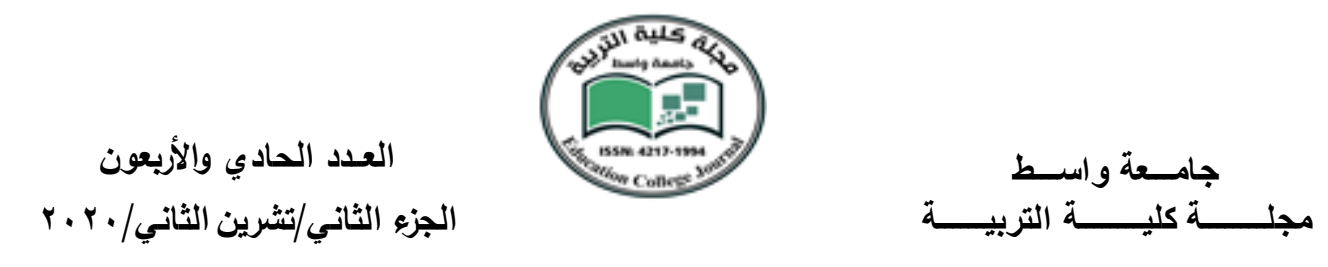

\title{
بنية التركيب المفارق في شعر الغزل الاموي
}

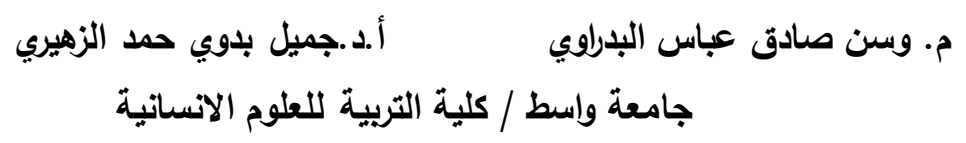

ملخص البحث

تباينت التراكيب البيانية والبلاغية التي تبناها الشعراء والناظمين منذ العصر الجاهلي ولغاية

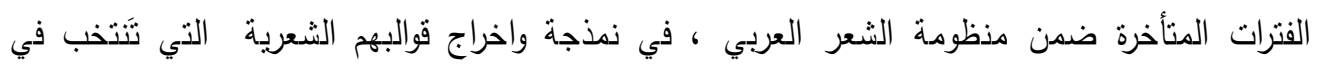
الاساس موضوعة المفارفة كتحول بياني اساسي في صياغة نلك النتاجات النصية ، وقد ارجعت مجمل ولم الفوارق التي ظهرت في تلك النتاجات عبر مراحلها المختلفة الى طبيعة البنى التركيبية التي اعتمدها الشعراء في كل وقت ، وبالنتيجة فان التمايزات التي طبعت مجمل ذناجهم المقفى ذي البعد المفارق كانت تعود في الاصل الى تلك الابنية وطرق اخراجها وتركيبها لترسيم صورهم المفارقة من خلالها ، عليه جاءت موضوعة البحث الحالي لنسلط الضوء على طبيعة تلك المخرجات بأبعادها المفارقة التي لتي اعتمدها شعراء الغزل في العصر الاموي في صباغة وتركيب ابنيتهم الشعربة .

\section{The structure of the separation structure in the Umayyad spinning}

\begin{abstract}
The graphic and rhetorical structures that poets and organizers adopted from the pre-Islamic era until the late periods within the Arab poetry system varied in modeling and extracting their poetic templates, which mainly elect the paradoxical theme as a basic graphical transformation in the formulation of these textual products. Its different stages refer to the nature of the structural structures adopted by the poets at all times. As a result, the distinctions that printed the entirety of their rhyming product with a dimension of differences were originally due to those structures and the methods of their output and composition to paint their paradoxical images through them, p. Why the current research topic came to shed light on the nature of these outputs with their paradoxical dimensions that were adopted by the poets of the spinning in the Umayyad period in formulation and installation of their poetic structures .
\end{abstract}


العدد الحادي والأربعون

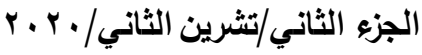

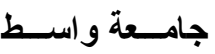

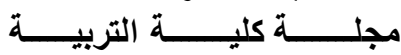

المقدمة

تعطي البنية النحوية انساقاً مستوحاة من طبيعة العلاقة الرابطة بين جوانب التمثيل اللغوي

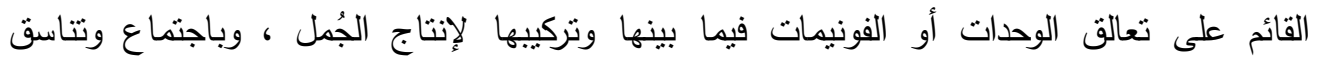

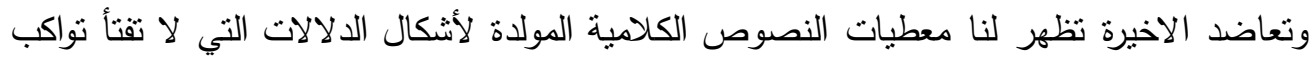
مجريات التحول الايديولوجي على مرّ التاريخ وعلى الصعد كافة سواءً منها النفسية او الاجتماعية ..

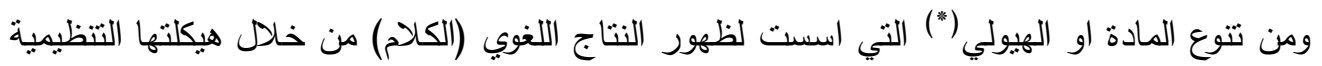
داخل بنية النتاج الذي سيكسبها بالمقابل الصورة أو الدغزى الذي يأتلف عليه مجموع السياق داخل

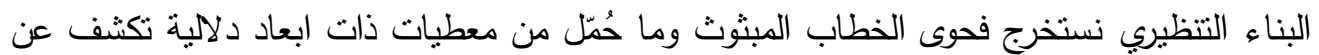

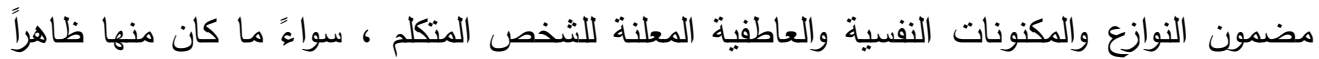

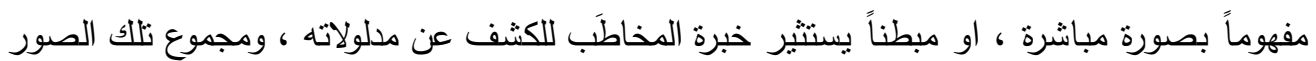

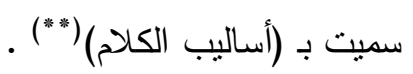

والتتويه فيما سبق يستحضر الأنساق البنائية على مستوى الخطابات الواقعية التي نباشرها

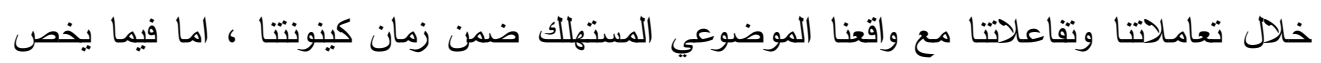

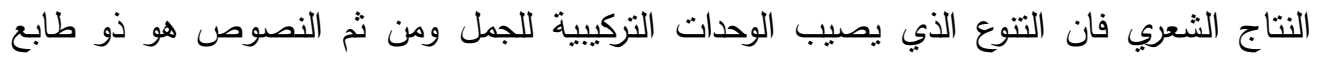

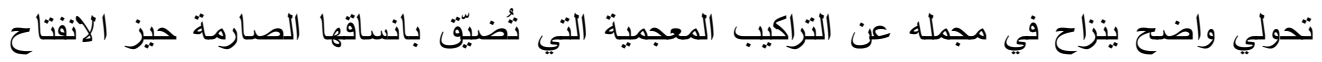
الذي تمنلكه العناصر اللغوية والسيل الدلالي وطرق الاستتباط التركيبي الدفارق الذي لا تحده حدود ، وتجعها رهينة للتراث النحوي ، فيما استفاد المتصدون لصناعة الثعر من تلك الخواص الديناميكية

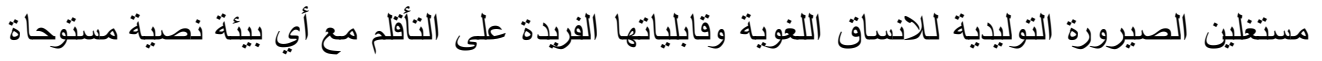
من وعي الثاعر وخياله ومفاهيمه وتصوراته النفسية والعاطفية ، فنتولد خلال ذلك اشكال سياقية تبتعد بطريقة او باخرى عن ماهياتها ذات التراكيب اللغوية الكلاسيكية المستهكة في معظمها مستثيرة انماطاً فنية جديدة ترنو بمجمها الى تأصيل الدور الجمالي المحفز لجمهور المنلقين ، على ان تلك

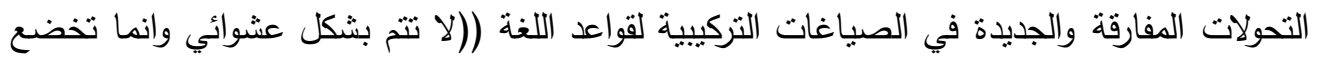
لنظامية واضحة وبطريقة تلفت انتباه القارئ الى ذلك ، فيدرك طبيعتها وكيفية بناء الثاعر لها))(') .

وعليه فان بنية التركيب المفارق لشعراء العصر الاموي نجدها قد منلت خاصية بنائية اتفقت رؤياها النكوينية على موائعة جملة الدوال الني تبناها شعراء ذلك العصر لنوليف صياغات نصية وخطابية مفارقة تتلاءم ومجمل التصورات والمفاهيم التي انتجتها قرائحهم الثعرية ، تلبية لحاجات 
العدد الحادي والأربعون

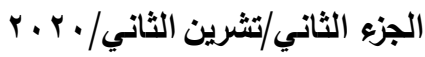

ونوازع داخلية اختلجت داخل منظوماتهم الفكرية والوجدانية ، فأصبحت نلك الدوافع بالنتيجة تبحث عن مخرجات تحايث بالضرورة قوالب بنائية تركيبية معدة لنتلبس مرموزاتها المصورة ، فاستبانت الصيغ البلاغية المقفاة معبرة عن المعاني والدلالات التي يطمح الناظم في ايصالها مقترنة بكيفيات جمالية تتعكس تأثيراتها الفكرية والمعنوية على جمهور المتلقين ، ومن خلال تلك التراكيب المحملة بعمق الرؤية الذاتية المقفاة لكل شاعر من شعراء الغزل الاموي ، تتضح تفاصيل الابعاد البنائية التي تبناها أولئك الشعراء في نمذجة واخراج نصوصهم المفارقة ، فجاء هذا البحث ليؤسس في توجهاته المنهجية طربقة للكثف عن الخواص اللغوية التركيبية المفارقة التي حملتها منظومات التشبيب لثعراء العصر الاموي ، ودراسة مستويات المفارقة اللغوية ضمن جوانب (الاضراب ، والاستثناء ، والتمني) التي اشرت حضورها في نصوص اولئك الشعراء

\section{البنى التركيبية المفارقة في شعر الغزل الاموي}

إنّ عملية البناء الثعري تعتمد التوافق التشكيلي والتركيبي في مجمل النص ، أبي انها تعطي للميكانزمات السياقية الاولوية في توليد المفارقة البنائية التي تستقطب من اشكال المثيرات الاسلوبية ما يتضح مجراه من خلال الرؤية الجمالية الكلية للنص ، فاستقراء النص الثعري على وفق الرؤية النسقية للغة سوف يشكل عائقاً في طريق خلق تضايفات منمنلة بالظروف والايحاءات وتعدد المعنى فضلاً عن استذعاء اساليب المفارقة وعدم التوقع والتضاد الناجم عن الاختلاف ، ومدلولات النظم التي تتنقل من مستوى البنية السطحية الى مستوى البنية العميقة ، التي بمجملها تمنل مجرى التركيب والبناء الثعري بصياغاته المتشاكلة . عليه فان السمة المانتة في الخطاب الثعري هي محاولة الابتعاد عن قوانين اللغة بانتهاك معياريتها وتلجيم علاقاتها البسيطة والمتداولة باتجاه الانزباح عن مستوياتها المعجمية لتوسيع آفاق التتوع الابداعي باستثارة الجوانب التأثنرية والجمالية التي تحفز معها ذائقية المنلقي وتسحبها الى منطقة التتويع والانفتاح الدلالي . فالتكوين البنائي والتركيبي المفارق للمفردات اللغوية ضمن المنظومات الثعرية لا يعتمد صفة التنظيم النحوي الصارم للوصول الى التوليفات المعنوية ذات الابعاد الدلالية المفعمة بالتنويع والابداع والخلق المستوفية للطبيعة الديناميكية الجوهرية للمعطى الشعري ، بل يتجاوزه الى محاولة ايجاد نوع من انواع العلاقات الجديدة والمبتكرة بين تللك المفردات بتتويع الصيغ غير المألوفة في تركيبها وتجاورها وتعالقها نلك ان ((التراكيب المفارقة ليست مجرد تكوين كلمات او مجرد تجاور 
العدد الحادي والأربعون

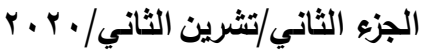

الفاظ بل ان اساسها يتمنل في مجموعة العلاقات المعقدة بين الكلمات حتى وان لم تكن متجاورة ، بل

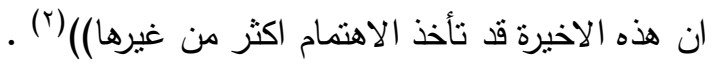

فالمفارقة في مستواها التركيبي تسلك مسلكاً اعم مما يظهر في مستويات الطباق والمقابلة التي تعتمد تطابق الدوال ، مرهونا بالتشاكل الذي سيتجاوز مستوى المفردات والصيغ الى مستوى تراكيب كلامية متنافرة ، تستطق المفهوم الدلالي الذي اشتط المعنى النسبي او النوعي ليستغرق على الجمع بين الفاظ منطابقة الى معنى الظواهر التركيبية لمجمل النصوص او المقطوعات الثعرية لتأتلف في صياغتها العامة فتشكل تراكيب النص المقفى بأكمله ، فالمستوى التركيبي هنا يعطي مفهوماً عن الضرورة السيكولوجية والتصورات والمفاهيم الشخصية التي تمخض النص المققى ليرسم ملامحها الدلالية وليستعين الثاعر بالمفردات والادوات التي تعينه على اخراج كيفياتها من القوة الى الفعل وسيأخذ الحديث والاستغراق في الاسلوب الحاضر من اساليب المفارقة بأصناف منها (الاضراب والاسنتناء والتمني) تعتمد ادوات معينة اجنرت من المجزوءات الثعرية لشعراء العصر الاموي في قوافيهم الغزلية بوصفها الاكثر حضوراً وتمايزاً عن مجاوراتها ، لذا اعتمدت الدراسة الحالية على تصنيفها وبيان معطياتها وابعادها التركيبية والجمالية ضمن تلك المنظومات . مفارقة الاضراب : - مفاب

تتولد جراء المفاهيم المتضاربة والصيغ المفارقة ضمن تحولات الخطاب ومجراه الذي ينتابه التشاكل والتضاد والتنازع في احايين كثيرة كصيرورة تتوافق والكيفيات الاعتبارية للوجود المتحقق ، مجموعة من الصيغ المتعارضة ضمن السياق الواحد ، وهذه الصيغ نتوافق مع ما في ذهنية المنكلم من معاني ينتابها اطواراً بعض النشاكل او التعارض او المفارقة في ابراز دلالاتها فيعرض عن المعنى الاول او الدلالة المقصودة باخرى مفارقة يعتريها الثك والتنازع نحو ما هو مستحصل من كيفياتها الخطابية فيحجم الناطق عما هو اعتباري الى ما هو حقيقي ضمن حدود معطياته الفكربة الواعية المنولدة في الزمان الآني لإنتاج الخطاب ، فينزع نحو عكس المفهوم ضمن السياق الواحد بطريقة استدراكية وبإحدى ادوات الاقلاب ليحيد عما قيل بآخر مخالف يسمى الاضراب ((وأضربت عن الشيء : كفقت واعرضت ، وضرب عنه الذكر وأضرب عنه : صرفهُ ، وأضرب عنه أي : أعرض)) (r) ، بمعنى ان في هذا النوع من المفارقة ((يضرب الناطق عما قاله فيما سبق ، ومن

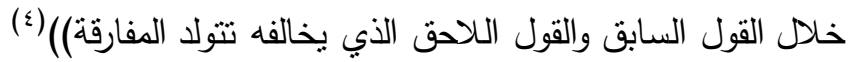


العدد الحادي والأربعون

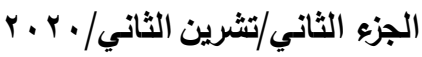

فالمفهوم الجديد المتولد من جراء قلب الدلالة او تعديل مسارها بحسب طبيعة الترسيم الدلالي لميكانزمات التحول اللغوي ضمن السياق الواحد يحتازه المتصرف بماهية النص وبالدرجة الاساس باتكائه على مجموعة من الادوات المعالجة لإشكالية هذا النوع من المفارقة للخروج بتتويعة دلالية تستوفي مؤثرات القيمة الجمالية التي تبثها مفارقة الاضراب محيلة اياه (النص) الى جدلية ذات نمط متجدد قادر على ان يبث روح التغيير المثمر في باكورة منونه النسقية لينطلق معها القارئ في اجواء من المعاني المنقلبة ذات المعطى الدلالي المنفتح ، بمعنى ان تلك الممارسات التحولية هي باب من ابواب التقاعلات الداخل نصوصية التي يسنكين اليها الناظم او الاديب ليرجح معها القيمة الجلية للمعطى الدلالي لتتوافق مع منطلبات النظم المنفلت من القيود اللغوية بنسقها المعجمي المنغلق فتحيد عن المسار المحدد لها سلفاً بما تفرضه مجريات اللغة ولوازمها محيلة النص الى مسار جديد ترجح معه خصيصة الاحتمال . ومن تللك الخصيصة تستطيع المفارقة ان تتوالد وتنتج معايير نصية جديدة تسنثير معها ميكانزمات التتوع الجمالي داخل حقولها الدلالية ، كون المعنى النهائي للنص سوف لن يقر وستبقى ارجحية الاحتمالات الواردة لاستقراء مفهوم آخر هي المتسيدة على ساحة الحكم والتقييم ومنها ستتوسع دائرة اشتغال المفارقة وتتشعب لتحيل القارئ الى اشكال من التصورات الواعية عن وقائع مخبوءة تماهي نوازعه البحثية للتقفيب والحفر في منون النص عما هو ثاوي ومتعالي عن نمطية الدلالات السطحية الى عمق البنية الفاعلة واستجلاء دورها بوصفها سمة دالة على شعرية النص التي (تتجلى في كون الكلمة تدرك بوصفها كلمة وليست مجرد بديل عن الثيء المسمى ولا كانبثاق للانفعال ، وتتجلى في كون الكلمات وتركيبها ودلالاتها وشكلها الخارجي والداخلي ليست سوى امارات مختلفة عن الواقع ، لها وزنها وقيمتها الخاصة)(م) ، لتحفز سيل متتابع من الايحاءات المعنوية المحايثة ، فتلفظ الغبار عن البنية السطحية متجاوزة لها نحو العمق لتفتح مسالك جديدة للنصوص تستطيع فيها ان تتلبس ((كياناً تجاوزياً دائم الانتاج والتخلق ... ظهوراً وبياناً ، مستمراً في الصيرورة

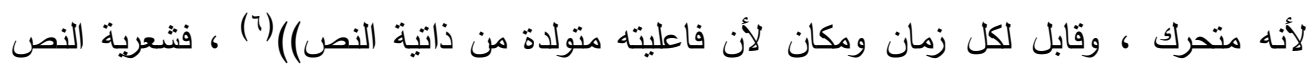
تتجلى بوصفها ((فضاء لنقاطع عدة شفرات تجد نفسها في علاقة منباللة ، تعني خروجاً بالعبارة عن حيادها الى اشكال وانماط مغايرة للمألوف ، لا يمكن معها احالة المدلول الشعري الى سنن محدة))( ال) ومع فن المراوغة ذاك ((تتحرك خطوط الدلالة في اتجاهات متعاكسة ، حيث تسلك في مسارها مسلكاً معيناً ، ثم تعدل هذا المسلك جزئياً او كلياً ، او ترتد عنه تماماً وهنا تلجأ الصياغة الى فئه 
العدد الحادي والأربعون

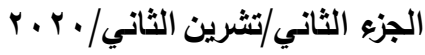

الاستعانة ببعض الادوات المعينة لمساعدتها في هذا التحرك المتعدد الاتجاهات)(^) ، ومن هذه

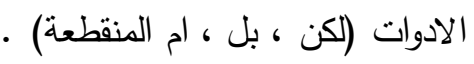

أما الاداة (لكن) فهي من الادوات او الحروف التي تقع تحت طائلة الاضراب ، فعلى الرغم من استعمالاتها المحدودة ضمن الادوات والحروف المعتمدة لدى شعراء الغزل ، إلا أن وجودها كغيرها من الادوات موضوعة البحث هنا مرتبط بعملية تحول تذفع للعدول عن المفاهيم المستتبطة فيما قبلها الى ما عداها ، تاركة المجال مفتوحاً لاستشعار مفاهيم جديدة تتاقض او تخالف البنية الدالية المتقدمة . الدان. وعمل (لكن) منل عمل (بلْ) ، تقرر الحكم لما قبلها ، وتثبت ضده لما بعدها ، ويسمى ربط الاستدراك او وصل النقيضين ، ويربط بين شيئين لهما المكانة نفسها ولكنهما يبدوان مثدافعين او بوها وهات غير منسقين في عالم النص ، أي الربط بين صورتين من صور المعلومات بينهما علاقة تعارض ونان كأن يكون سبباً ونتيجة غير منوقعة (9) ، كقول عمر بن ابي ربيعة (من الطويل) :

مَسَارِبُ عَينَيَّ الأدمُوعُ السَوَاجُُِ

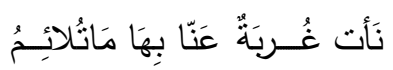

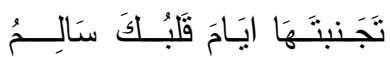

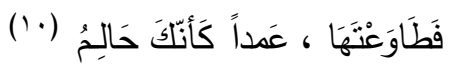

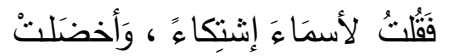
أُبِيني لَنَا ، كَيفَ السَبيلُ إلى التِي

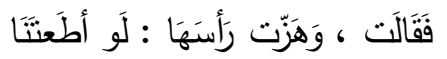

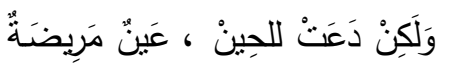

استبان ضمن المجزوءة موضوعة التحليل انزباح الثاعر عن التشبث بمعيارية اللغة

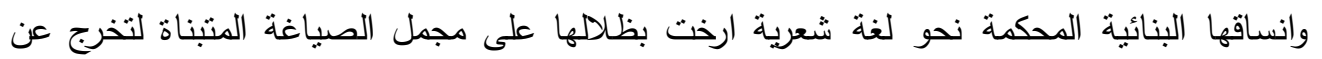
مضمار المعطى الدلالي المستوفي للمعنى المستكين لصورة واحدة الى العدول لمبدأ التنوع للضرورة الشعرية بالاستعانة باللوازم المفارقة والتي منلت هنا الاداة (لكن) ((وهي حرف ابتداء يفيد معنى الاستدراك وتقع بعد الايجاب والنفي)("') ، فتحول مجرى الخطاب من سؤال الثاعر الى جواب العرافة ، ومن الندب للانقطاع عن الآخر وشُقَة الصلة ونشيج الثعور ، وسجم فيض المدمع من الطرف الاول الىى التقريع والتعنيف بسلبية الطباع والضآلة والخور امام تأليب مكامن اللذة من الآخر ، وهذه التحولات في مجرى الخطاب تبناها الشاعر لتشكيل صورته الشعرية واظهارها بهيئة مفارقة ، وادارة ذلك الانزياح اعتماداً على الاداة (لكن) كما رفد بالأفعال (فقالت - هزت- دعت..) المسندة الى ضمير الغائب لإكمال وصل النقيضين في الصورة اللاحقة 
العدد الحادي والأربعون

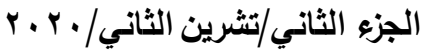

وفي محمل آخر تتواطأ اجمة الخطاب لخلخلة المعنى المتساوق في بادئية التصريح حتى تستدرك القارئ الى استشفاف دلالي متقدم مفارق للمتأخر منه ، فبالمقاربة الدلالية بين الصورة بله النتبيهية الاولى في انطباعاتها البنيوية وبين المعطى الكامن للتك النزق الوجودي في قول العرجي (من الطويل) : (من )

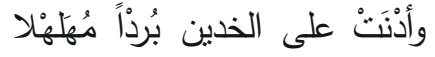

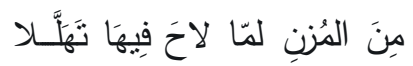
وَلكنْ لِيقتَلْنَ البَربيءَ المُغَفَـلا

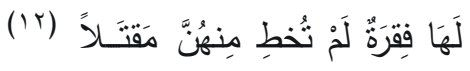

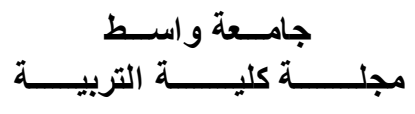


العدد الحادي والأربعون

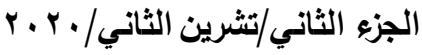

وفي صورة اخرى لمجنون ليلى يستدعي فيها الاداة (لكن) ليعقد هذه المرة نمط مقارن يوافق فيه بين نسق وجودي ينسدل تحت تصورات وجدانية اعتبارية ، وآخر ميتافيزيقي خاضع للضرورة العقائدية في ترسيم مالاح الوجود المفارق وما ينطلي عليه جزاء المخالفين لتعاليم واحكام المعبود من عقاب حينما يقول (من الوافر) :

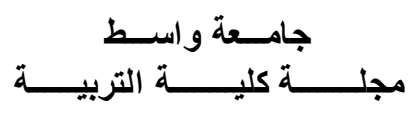

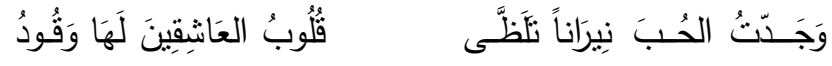

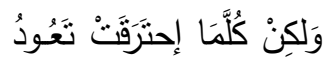

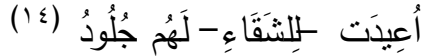

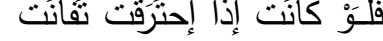

فما بعدت الثقة بين المعنيين من خلا تحقق وجودهما المناقض وتلازم زمانهما المفارق فحسب بل مما ساعد على توسيع الهوة تفعيل الاداة (لكن) التي اضافت لطرفي المفارقة تصورات حضورية وليس معنوية فقط ، فما ينطلي على معاناة المعذبين في نار خطاياهم الابدية التي لا نرحم

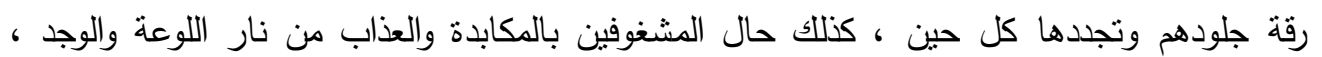
وايضاً مما رصن حضور هذه المجزوءة وعمق تأثيرها هو ملازمتها التتاصية مع فحوى الخطاب القرآني ، وهي التفاتة ليست بالغربية على شعراء الغزل العذري الذين استلهموا معاني القرآن الكريم والفوا دواله وما تمنلكه من قوة وسطوة تستميل معهما شغاف القلوب ، فجعلوا بعض من خطاباتهم تسنلهم من نلك الدوال والمعاني لترصين دلالات نظمهم وايغال اثرها في النفوس • وعند الثاعر (الصمة القشيري) تسندعى الاداة (لكن) لتغيير نمط التعبير عن وعي الادراك الحسي المنفلت من حالة الكمون والابلاس وانعكاسهما السلبي على معالم الجسد المادي ، بتغبير ملامحه واستتزاف قدراته ونتويه سيمائه ، الى تبني البوح بالجهر عن مكامن الوجدان حسب السياق الانثروبولوجي المعتمد بالاستكانة للمدمع في قوله (من الطويل) :

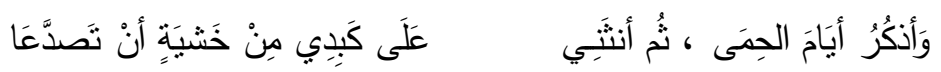

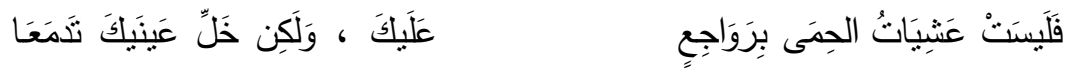

فاختيار المدمع ككيفية للتصريح والتعبير عوضاً عن تعنيف وتعذيب الكينونة المادية جاء مسبوقاً بـ(لكن) التي فارقت في مجرى السلوك من حالة انتقالية الى حالة معتمدة ، فتمكنت من تحقيق المفارقة الاضرابية في النص مبك 
العدد الحادي والأربعون

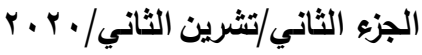

واستقرار الحال عند (جميل بثينة) بتبني مشروع الكتمان عن ناظريه خوفاً من شيوع امره عدا لحظات الخَزَر بينه وبين مودوده الباثة لشفرات تعلقه التي سبقها بـ(لكن) ليعول عليها في قادم سلوكه الوجداني فانشد يقول : (من الطويل)

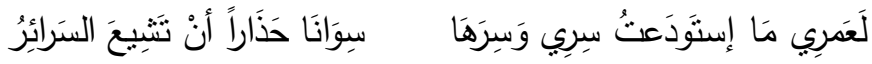

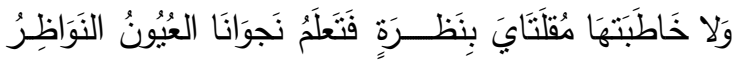

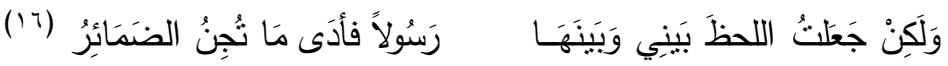
فنسق التحول الدلالي لم يكتمل في بنائه المفارق الا بذخول الاداة (لكن) التي مكنت

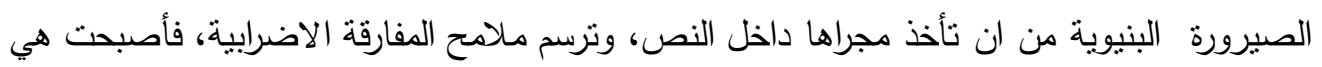
بؤرة الخطاب وذراع الميزان الحامل لكفتيه المتتاقضتين ، وعملية الموازنة تعود بالأصل الى براعة الثاعر وقدراته البيانية في تشكيل دواله البنائية وسياقاته الدلالية ـ فالأداة (لكن) عملت على تبيين الجانب الوجداني لدى الثاعر وسمو نفسه عن الاشياء المألوفة في سير المتولهين . كما ظهرت الأداة (لكنّ) من ادوات الربط ضمن النتاج الغزلي للحقبة الاموية ، اعتمدها البعض من شعراء النسيب في مسعاهم الدلالي المتحقق ضمن معنى الاستدراك (كونها تُسبب لما

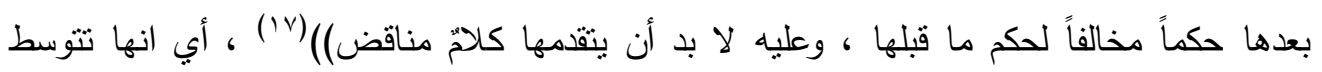
طرفي التناقض او المفارقة لتجمع بينها ضمن سياق المنظوم الثعري ، وليس اوضح من تمكينها على خلق معنى منسم بخاصية التحفيز الخلاق لتعميق قوة الرابطة بين المتلقي والنص الشعري الذي

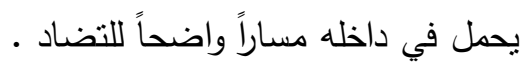

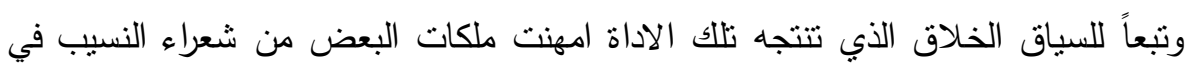
استدراجها ضمن خطاباتهم كما عند الشاعر (عبيد الله بن قيس الرقيات) في قوله (من المنقارب):

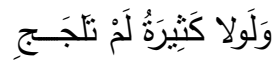

$$
\begin{aligned}
& \text { لَجِجتَ بِحُبِكَ أهلَ العِراقَ } \\
& \text { كَثَبِرَة أخْتَ بَنِي الخَزَرَجِ } \\
& \text { فَلَيتَ كَثْرَةَّة لَمْ ألَقَهَبـا }
\end{aligned}
$$

الخطاب الداخلي للثاعر ينم عن مواجهة تصريحية بمدعاة اللهج بحب اهل العراق وحصر الدافع من وراء تلك الميول الى الانموذج المتعالق (كثيرة) وايداع الثعور المفارق الذي استوطن بواطن الناظم لذلك المثال ، واستكمالاً لمأثور تلك الخلجات والتصريح بها يستقطب الثاعر الاداة (لكنّ) حتى يصرح للمنلقي بميوله اتجاه ذلك الرمز الانثوي المتعالي في صفاته الحسية ، والمحجوب 
العدد الحادي والأربعون

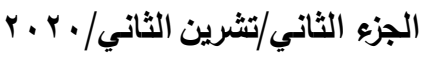

بالوقت نفسه عن استطاعته ، فتوسطت الاداة (لكن) طرفي النقيض ما بين ميل الثاعر وتعلقه بذلك

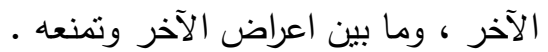

والاداة الاخرى من ادوات الربط التي استحوذت على اهتمام شعراء الغزل في العصر

الاموي هي الاداة (بل) التي يرنو مستعمليها الى تقوية نراكيب الجملة ، وايضاً يعتمد عليها الشاعر للربط بين جملتين يسعى من خلالها الى اثبات المعنى الثاني على حساب الاول فهي ((حرف عطف

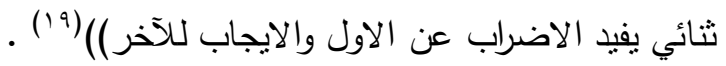

ومن شعراء العصر الاموي ممن بان توظيفه واستخلاله للإمكانات اللغوية التي تحققها تلك الك الاداة هو (عمر بن ابي ربيعة) في مجزوئته الحاضرة التي طبعت حيثياتها باسلوب الخطاب المنقابل

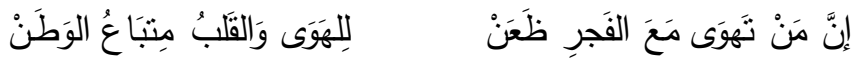

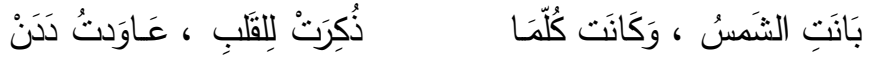
في قوله (من الرمل) :

لاتُؤاتِينِي وَلَيَسَتْْ مِنْ وَطَنْن وَلَئِنْ أمسَتنْ نَوَاهَا غُرَبَةُة لِعنَاِِ آخِـرَ الدَهرِ ، مُعَسنْ

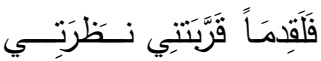
شِقوَةُ العَيشِ، وَتَكليفُ الحَزَنْ

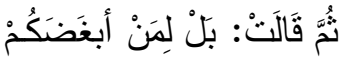
بِكَرِيحٍ ، لَوْ يُرَى أو لَوْ يُكَنْ

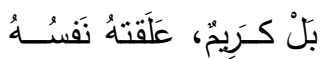

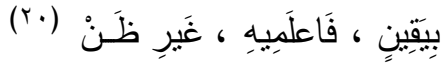

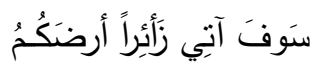
فالأطراف التي تتاوبت في تشكيل لغة الخطاب مع الناظم استثرها الاخير ليحقق البعد الدلالي الذي يصبو اليه ، فعلى الرغم من النسقية المتبادلة في لغة المنظوم الا ان بؤرة التحول والتركيز خصت الطرف الآخر المعني بالاهنمام ، فأصبحت دوالها بعد تمييزها بإشارة الكلام (قالت) معرضة بالأداة (بل) هي المعول عليها في ترسيم ملامح الخطاب وجره نحو التقيد بتلك الدوال وما

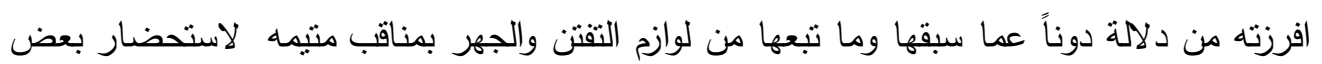

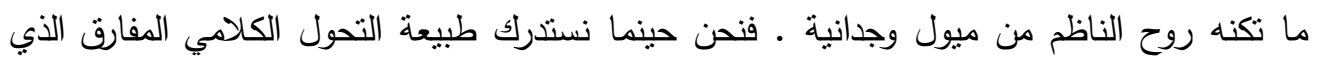
تبذاه الثناعر في المجزوءة الحاضرة ليحول معه الانظار والافهام الى عبارات شغفه ، نذعن للخاصية المميزة التي تمنلكها تلك الاداة (بل) وقابليتها الاستتباطية في جعل جميع العلامات اللغوية الواردة في النص السابق لها ضمن السياق الاعتباري دوناً عن المفردات التي تليها المخصوصة بحقيقة التتبيه 
العدد الحادي والأربعون

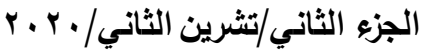

والتأكيد والتفاعل البناء مع المثلقي ، فالأداة (بل) ((بعطها تجعل ما قبلها مسكوثُ عنه وتثبت الحكم

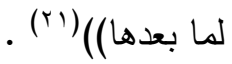

وتتشكل بنية مفارقة عند الشاعر (قيس لبنى) ضمن الابيات الحاضرة منلبسة بهيئة مفارقة

اضرابية مستعيناً بالأداة (بل) لإقامة حد فاصل بين دلالتين تتماهيان لتبيان التحول الخطابي بكيفية تنخله ضمن دائرة التوقع والتخمين ، على أن الارجحية في عملية الاستتباط الدلالي سنؤول لصالح المعنى البعدي وليس القبلي وحسب ماتقتضيه لازمة حضور الاداة (بل) في منن الخطاب وفيه إذ

$$
\text { قال (من الطويل) : }
$$

فَظظلَّت عَلَيَّ العائداتُ نَفَجَُُّْ

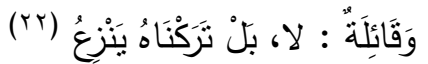

صَبيحَة جَاءَ العائداتُ بَعُدنني

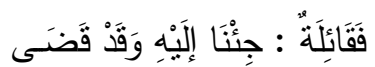

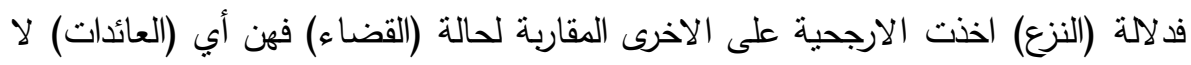

يدركن التصوير الامنل لحالة المفجوع المسدل جسده ينازع بين الكينونة والعدم فيضربن بعصى التخمين تارة بين نهاية ملحمته الوجدانية واخرى تميط اللثام عن بقية باقية لم يقضها شلو القدر فتتازع اطراف الخطاب المفارق كما ينازع المغلوب على امره اكماد التوله ، لتستقر عند بيان التقرير المسبوق بالأداة (بل) فتنقلقل حال العائد وهو ينازع طرفي الوجود ليبقى معلقاً تصارع فؤاده مكابدات الشوق المضنية ـ فالبنية التصويرية في هذه المجزوءة تذل على براعة النظم وروعة البيان ومسار اللغة الامنل الذي تبناه الثاعر هنا ليعطي دلالات عميقة في بضع دوال ، حملت على عاتقها توثيق المعالم الجديرة بوصف تصورات الحالة الاعتبارية التي كابدها، كما تحققت صورة متتاقضة تشاطرت طرفي او قسمي البيت الثاني بعدما نكررت لفظة (قائلة) في بداية كلا المقطعين لتلل الاولى الى وقوع حالة الافتراق والتصرم لكيان الثاعر عن عالم الوجود ، أما الثانية فلم تؤكد سوى استمرار حالة المنازعة وعدم اقرار التثبت من مفارقة المتوله لواقعه ودخوله حالة العدم ، ودللت تلك المسالك المفارقة التي تحققت في المجزوء الحاضر على مجانبة الشاعر لهذا التتويع البلاغي بغية استحصال المعنى والتأكيد على اهميته بالنسبة اليه وكذلك توسيع مديات التواصل والتفاعل بين المتلقي والنص . ويحدث اضطراب في البنية السيكولوجية لثاعر آخر هو (عمر بن ابي ربيعة) وتشود معطيات التخلخل للمفاهيم القبلية المتوارثة لديه بعدما تتازعت روحه اطراف الحرمان من هجر ضعائن المودود دونما سابقة معلنة ، فبانت شفرات مفارقة الاضراب متحققة في مقاطع نظمه يسودها جو من الجدل في الدلالة ، وتقلب في صياغة الدوال بإخاله للأداة (بل) ومراودتها بين معنيين سابق ولاحق ، والمعول كما هو معلوم سيكون للاحق في سيادة المضمون ، كما في قوله (من الكامل) : 
العدد الحادي والأربعون

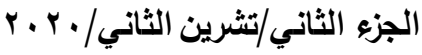

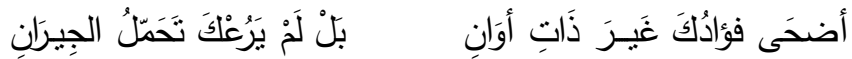

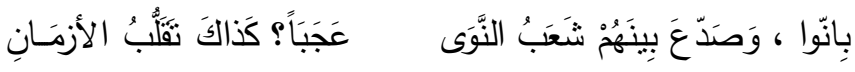

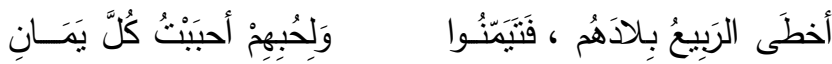

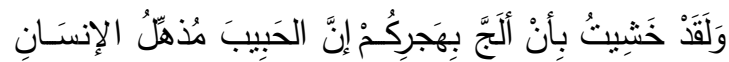

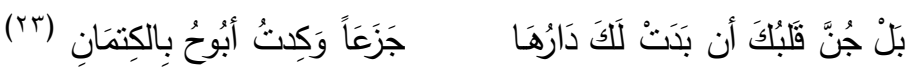

وتتكرر مقتربات الضرورة الشعرية في شعر (عمر بن ابي ربيعة) في إعادة

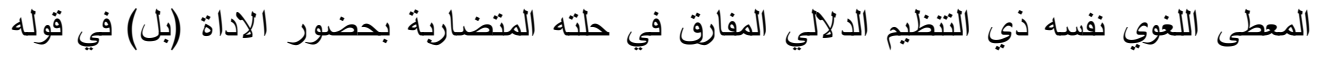

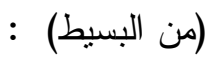

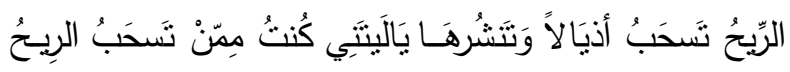

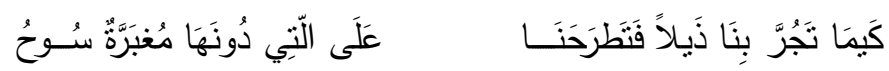

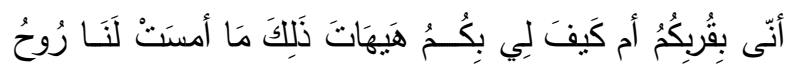

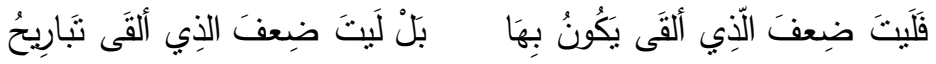

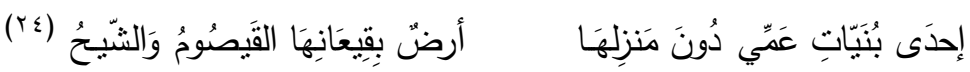

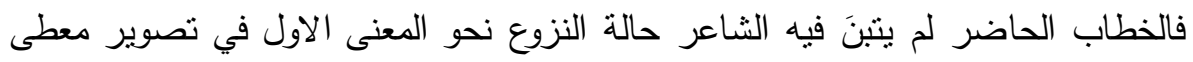

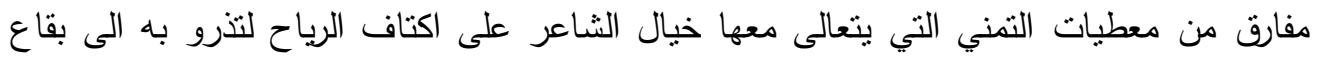

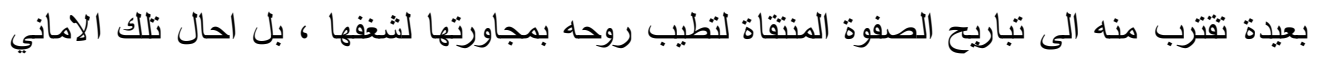

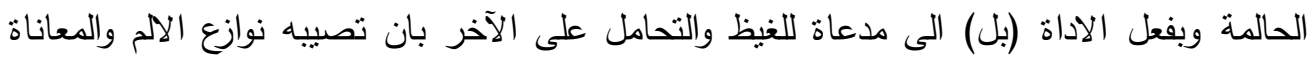

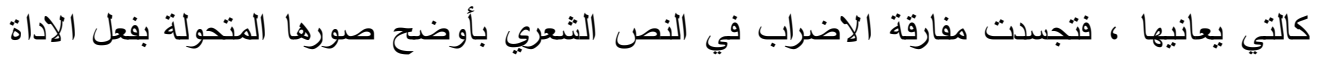

وضمن صورة اخرى من صور مفارقة الاضراب التي انكأ فيها الشاعر على البنى الثى

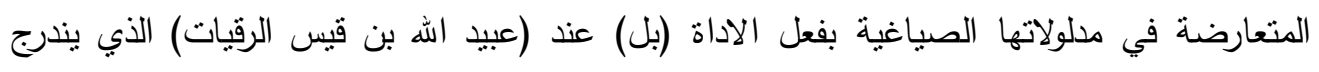

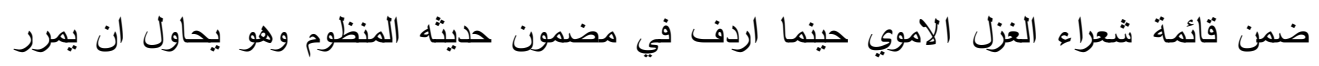
اللمنتلي ما يخالجه من معطى شعوري اتجاه من تعالقت فرائضه بحباله في قوله (من الهزج) :

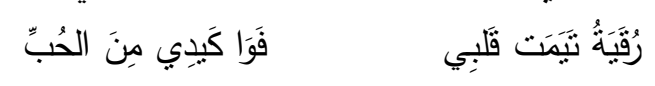

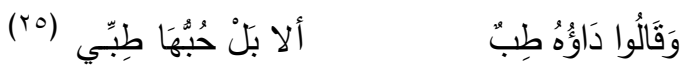


العدد الحادي والأربعون

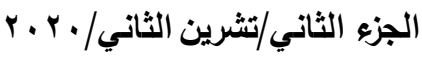

اذ تتم الدوال اللغوية في المجزوءة الحاضرة عن بساطة في انتقائها من قبل الناظم فقد ميزت بناها النسقية عن مفردات مسنوفية لمعناها الصريح دونما تكلف او غموض ، فانتظمت في سلاسة تصور ماهية موضوعها حينما تحول بحد ذاته الى محمول يعول عليه فيما كان هو سبباً في وجوده ، وكأن الناظم يعكس في قوافيه قول الثاعر الحكيم (وداوي بالتي كانت هي الداء) ، فقلبت الاداة (بل) ظاهر الخطاب والمعنى لتكثف عن مفارقة اضرابية تحول فيها الداء الى علاج في نظر المتوله ، بينما تضف (ألا) كأداة استفتاح تهيمن على الجواب الصحيح وتقدم له ترابط الاضراب بعبارة (حبها طبي) ، فنزداد المفارقة بعداً ويظهر التوله على اثده . وتتجلى بنية الاضراب عند الشاعر (الحارث المخزومي) في معطى نشبيبي ذي ونيرة انفعالية متصاعدة استعان الثاعر بدواله التصويرية ليقرب للمنلقي غور مكنوناته الوجدانية اتجاه الآخر المحايث للشعور التي تخطت حدود ومديات المفهوم العقلي بل وتجاوزت عليه حتى استلبته مقومات الفعل المنطقي ، فكيانه مهزوز ومقوماته الفكرية مهدة بالضياع في اية لحظة جراء الضغوط العاطفية التي يتعرض لها من قبل الثريك ، فالمعنى الغزلي جانب مفهوم المفارقة حتى بدون الاستعانة بالأداة (بل) التي اضافت هي الاخرى بفعلها الاضرابي صياغة اقرب ما تكون الى المبالغة والتجاوز على عناصر الجنس الانثوي في قوله (من الخفيف) :

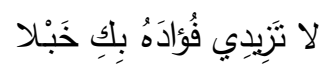

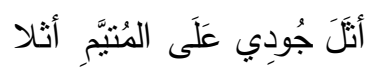

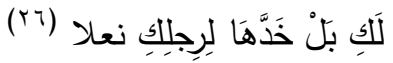
جَعلَ اللهُ كُلَّ انتَّى فِـدأًَ وسيان بين ما تفرزه الادوات اللغوية من تباينات على مستوى المعطى الدلالي ، وبين استعمالها في المعطى الشعري ، فان الكيفية المتحقة سنصرح بالضرورة حدوث معنى المفارقة الاضرابية ومظاهر التحول الدلالي في البنية الثعرية ، التي ستتحقق بالأداة (أم)(**") ، أو ما بطلق على طابعها التحولي بـ(أم) المنقطعة ، إذ برزت هذه الاداة في الصور الشعربة لبعض شعراء الغزل الاموي مستفيدين من امكانياتها في التحول النسقي الاعتباري للمدلول الشعري ونوسطها لمظاهر الانقلاب الدلالي بنماهيها بين نمط سلوكي وآخر مناقض ومفارق له ، على اساس ما نملكه من حدود المجادلة ومن ثم تفعيل الامكانيات الديناميكية في النص ، فيتحول بفعلها الى مسرح تتضايف فيه الدلالات في جدلية متفاوتة محققة للطابع الجمالي ومبرزة له إذ تسعى الخطابات المنظومة

$$
\text { والنصوص المسرودة الى تحقيقه . }
$$


العدد الحادي والأربعون

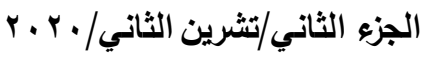

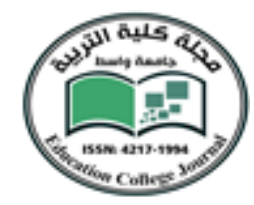

ومن النظم التي فعلّ تلك الاداة ضمن صورها الشعرية الغزلية ما تحقق منها عند الشاعر

$$
\text { (جميل بثينة) في قوله (من الطويل) : }
$$

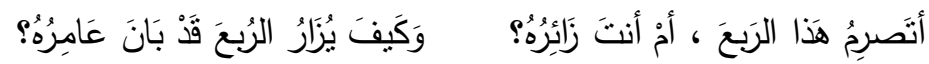

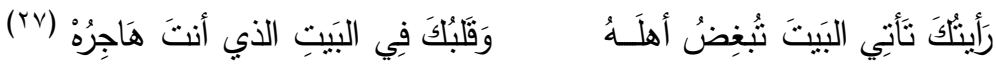

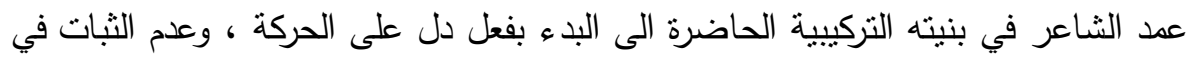

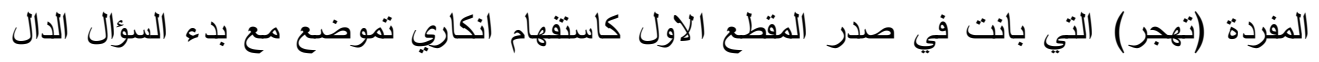

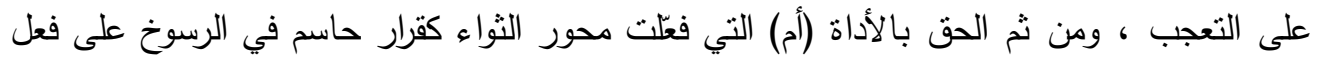

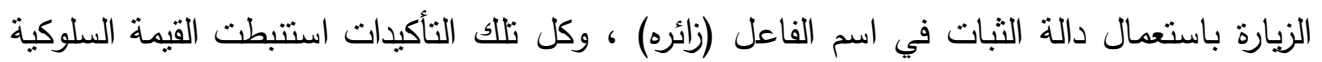

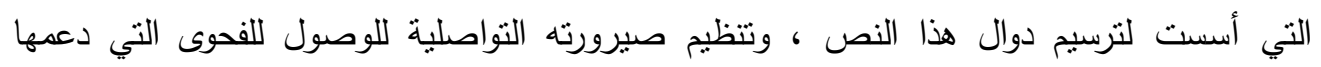

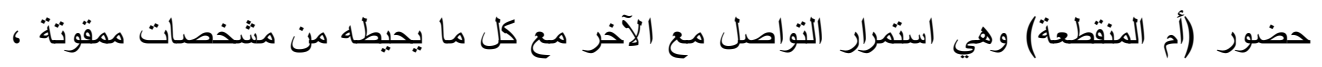
في سبيل ندعيم الجانب الروحي ، وبقاء المتعالقات الوجدانية ذات الصلة بالكائن لذانه الحائز للقيمة

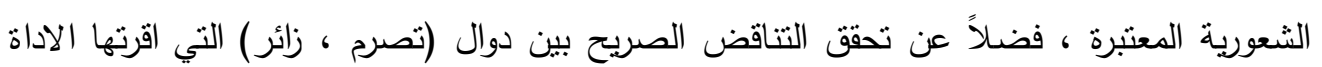

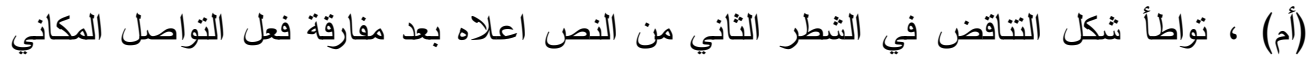

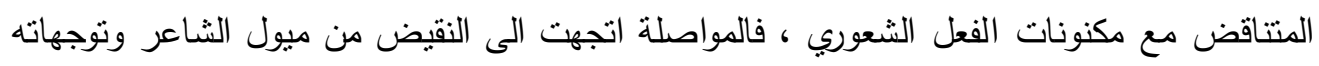

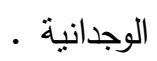

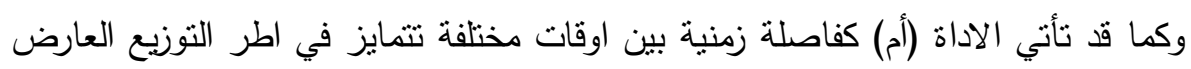

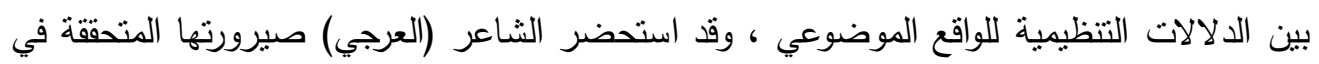

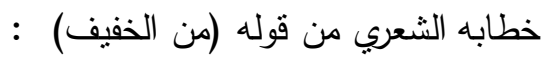

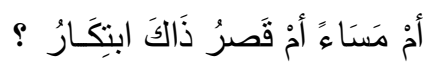

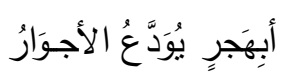

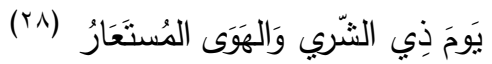

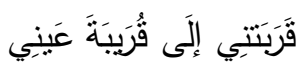

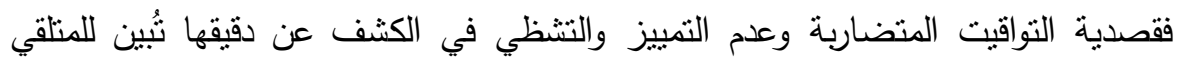

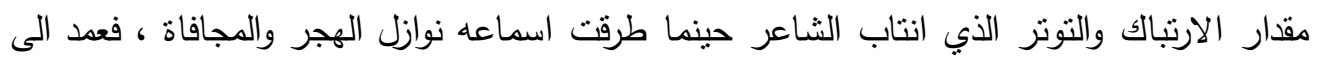

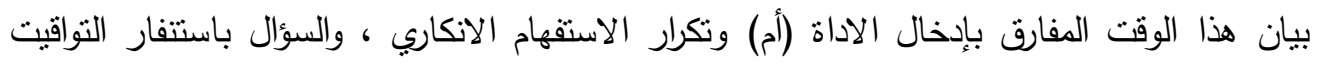

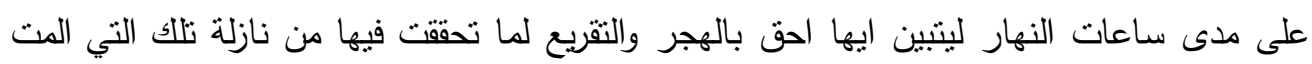

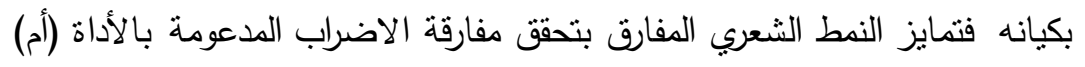


العدد الحادي والأربعون

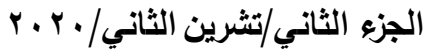

ونستدل على نمط مفارق آخر مردف بالأداة (أم) في البيت الشعري لـ(عر بن ابي ربيعة)

$$
\text { والذي استهله بقوله (من الوافر) : }
$$

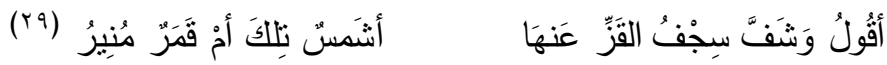

\section{يكثف الخطاب المنظوم عن قيم جمالية تشبيهية تخيم عليها نمطية منواترة الفنا موتيفاتها}

في كثثر من خطابات الغزل ، الا ان تلبس نلك الرابطة الشعرية بقالب مفارق واستحضار الأداة (أم) التي اخلت بالمعنى السابق لها وتبنت اللاحق ، اظلَّ على النص الحاضر بطابعيه مميزة انسلخت عن مماثلاتها من النصوص الاخرى ، لتكشف عن مقدار التتوع اللغوي الذي ميز اساليب شعر الغزل في العصر الاموي والامكانات الديناميكية في تتويع الدوال التي احتازها ناظميه ((ففي عصر بني امية اتخذ شعراء الغزل هذا النمط الشعري كصناعة منقنة وفناً مختاراً لا يتكلفون غيره ولا يعنون بسواه)) (·r) ، كما عكست الاداة (أم) بعد نوسطها للرموز الطبيعية (شمس ، قمر) الدالة على تعالي المعنى الجمالي عن القيم الثكلية المعهودة ، نبني الثاعر من السمات الحسية ما لا يعلوها في التمايز شيء

وكنلك نطلع على انموذج من المفارقة عند (جرير) يخير نفسه فيه بين التقصي بالنظر أو تكلف مشقة اللحاق بالركب المرتحل ، بما يحويه من كيذونة متأصلة في حضورها وتفردها المطلق بنق في وجدان الناظم ، وفيه الزم الثاعر نفسه في تخريج خطابه بإعطائه صناعة ذات ابعاداً مفارقة تتعاضد مع الماهية المتحققة بوجود الاداة (أم) التي فعّلت المعنى اللاحق ، مع خروجه بآلية للاستقهام تكررت فيها اداة الاستفهام (هل) ، مما اسبغ على السياق التصويري لبنية النص الثعري قيمة مضافة من قيم التلام الشعوري المتقد الذي خالج مكنونات الثاعر المضطردة في قوله (من (الكامل)

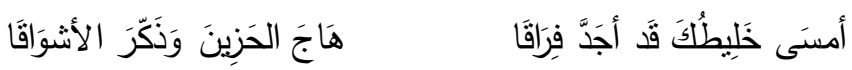

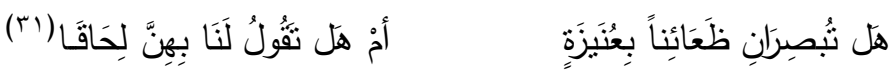

وقد تأتي (أم) في البيت الشعري الذبي يلي بيت الاستفهام ، لتحقق الترابط ، فتراكيب اللغة العربية على كثرتها ، نراها نكتسب أهميتها من صور الترابط ، وهذا ما حققته (أم) في قول (العرجي)

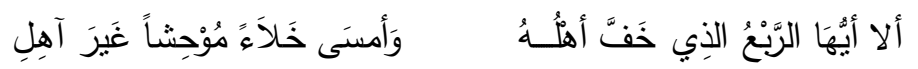

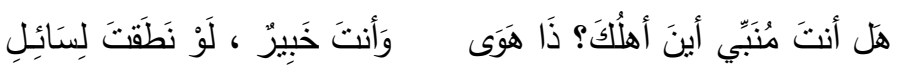

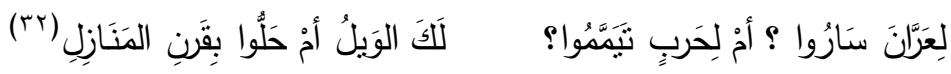


العدد الحادي والأربعون

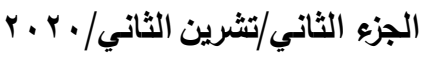

فالترابط اللغوي يحقق بالنتيجة ترابطاً دلالياً يؤطر بنية الخطاب الشعري ويحقق الثيمة التعبيرية التي نتراكب لأجلها البنى اللغوية وتتجاور ، فتشكل قوالب التأصيل لكيفيات الطابع التحولي لكل انموذج ، وفي كل مرة تؤسس لحضور سمة تشكيلية جديدة تجير لصالح ناظمها ـ وفي النص الشعري الحاضر الذي يختلج فيه خزين التساؤلات وجدان الناظم فينازع ثقل التصورات التي المت به ويحاول اسباغ طابع الصدقية على بعضها بنقديم الاداة (أم) عليها ، فينتزع تحققاً ولو اعتبارياً حتى تستقر مسارب النفس ، وتلملم شتاتها المنشظّي بفعل هول الفراق فبرزت مفارقة الاضراب لنشكل تبايناً لغوياً بفعل الاداة (أم) ولتحثث ترجيحاً لبعض التواقيت على بعضها الآخر في ملحمة تفاعلية حايثت في بضع دوالها عمق الانتماء الوجداني والمفاهيمي اتجاه الآخر . فالنسق العاطفي الذي تُشّر له ومن اجله كل المعطيات سواءً منها الزمانية أو المكانية او

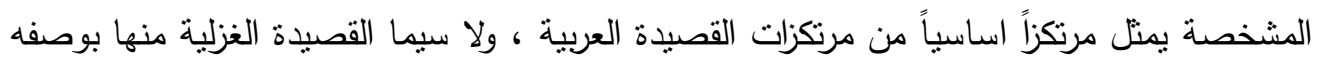
محوراً بنائياً في هيكلها الشعري كونه متجذراً في بواطن اللاشعور ، والاحساس به حالة فطرية وغربزية جُبل عليها الانسان ، فضلاً عن أن ذلك النسق يمثل محوراً مباشراً في انتاج القيمة الفنية للنص التشبيبي ، على اساس ان العاطفة ما انفكت لان تكون محفزاً أساسياً للفعل الانساني • فالعاطفة لها التباسات ومفارقات ، ولها كذلك اخفاقات بوصفها حدثاً مفتوح الاحتمالات له له جملة من التأويلات المختلفة في رؤاها ومنطلقاتها تبعاً للذات الحاملة لهذه العاطفة ، ودرجة النأصيل المتموضع منها داخل النفس فيتبع ذلك بالمقابل مستوى الضواغط العاطفية المؤثرة في مسار الذات وطريقة تعاملها مع الواقع ، لان الآثار العاطفية تخضع للتذاخل العام بين توترات الانقباض والامتداد كوذها تمثل منبع الاثر العاطفي الذي يجعل كل عبارة عاطفية بمثابة اداة شحن وتوليد لعبارة اخرى ، فتحفز تلك المظاهر الملكة الشعرية لدى الناظم الغزلي ليواظب على تعميق مجرى الدلالة العاطفية من خلال نهجه البنائي الخاص بتجربته الشعورية . مفارقة الاستثناء : تتلبس انساق المفارقة في مفهوم الاستثاء طابعاً انتقائياً تستتبط فيه احداثيات التحول الدلالي مجراها المحدد من خلال احدى الادوات المحققة لذلك المفهوم ، فتتلبس مجريات الطابع التحولي بمعنى ينسلخ من خلاله المضمون القبلي عن البعدي ، وكما جاء في مفتاح العلوم فالاستثناء هو ((اخراج الشيء عن حكم دخل فيه غيره))(rr) ، وباستقراء اساليب الاستثناء وتتوعاتها نستمكن من فن معاينة النمط البنائي القابع وراء التمثلات الكيفية لأوجه تحققه في الخطاب وصيرورته ضمن حدوده 
العدد الحادي والأربعون

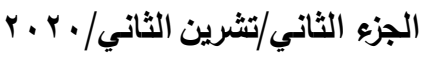

المعطاة عبر متضايفاته من الحروف التي لا تتخارج صور الاستثناء الا بحضورها وتفعيلها لهذا النمط اللغوي ، ومن اهم هذه الحروف واكثرها تمايزاً في هذا النوع من اساليب الكلام هي (إلا) . والاداة (إلا) تعد اصل حروف الاسنتناء وهي المسؤولة على هذا الباب ... وانما كانت هي الاصل لأنها حرف ، وإنما ينقل الكلام من حد الى حد بالحروف (عَ) . كما ان الامكانات التي تمنلكها (إلا) توجد في غيرها من الادوات التي تؤسس للخطاب المفارق بطابعه الاستثنائي ، على اساس ان حضورها يشكل مقاربات للنمطية الانتقائية في الدلالات المتحققة في النص ، فتعمل على استبعاد الاثر المعنوي لما قبلها على حساب ما بعدها في النفي

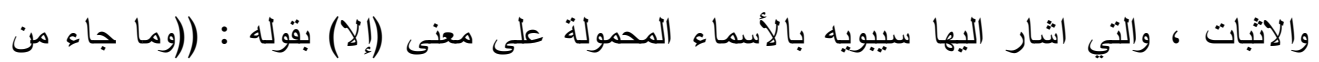

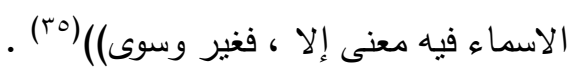
وبالتقصي عن استعمالات هذه الادوات التي تستحضر مفهوم المفارقة في بنية الاستثناء في منظومة الغزل للعصر الاموي ، تستوقفنا مخرجات تسنكين محمولاتها في معظمها الغالب الى الاستشهاد بـ(إلا) كحرف اخذ الحيز الاوسع من الحضور في منظوم تلك الطبقة من الشعراء وكانت له دلالاته المتمايزة تبعاً للموقف الثعوري الذي يصوره النص الشعري ذي المأخذ المفارق ، وبداية نستشهد بقول (القطامي) الذي يبث من خلال خطابه مقدار الاحباط والانكسار الذي انعكس في ردود الافعال السلبية للشريك ، واستهانة الآخر بأحقية ثثين مكتسبات الرابطة الشعورية التي جمعته

وَطَاَوعَتْنْ بِكَ مَنْ أغَرَى وَمَنْ صَرَمَا

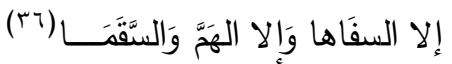

بالثَاعر حينما قال الأخير (من البسيط) :

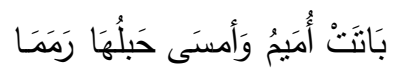

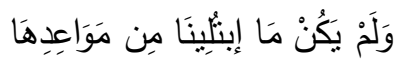

فالقرين ميز حكمه المجحف بقطع الوصل والتصرم فضلاً عن الانقياد خلف من يتحينون ويتربصون الدوائر للتفريق ، وتكرار الاداة (إلا) افرز حالة من الامتعاض والسخط تجاه هذا الانموذج الفاقد لأشكال المعطى الثعوري في ابسط صوره الانسانية ، واحقية التسليم بعدق الرابطة الوجدانية التي تجمع طرفي التعالق ، كما افرز النص الشعري نوعاً من الاستعارة التصريحية التي استعاضت عن اشكال الاتصال والارتباط الوجداني بأيقونة الحبل الذي يصل بين طرفين ، وقد اجازت الاداة (إلا) بتكرارها احقية البواعث المحفزة لأشكال الامراض والهموم في تمثيل صورة الآخر وتعميق فحواها

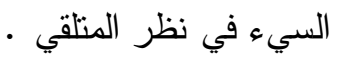
ويستوقفنا مثال آخر وُظِّف ضمن دواله حرف الاسنثناء (إلا) في نص شعري يستثير معه الثاعر موقف التلة المنغمسة بإحدى براثن الثذوذ النفسي المقيت الذي يستمد آليات بقائه وديمومته 
العدد الحادي والأربعون

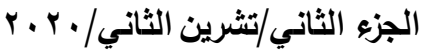

النزقة على حساب حيواة الآخرين وبالأخص من ارتبطت نوازعهم الروحية والوجدانية برابطة الود والتعالق ، ولسان حال الناظم هو الرثاء بعد كل مالقيه من دسائس ومكائد هؤلاء ، فقي الوقت الذي يتجافى فيه عن أغراضهم العدوانية ويقابلها بالضد ، إلا ان تبعات تلك العوارض تبدو اثارها السلبية على البنية النفسية للثاعر فنتولد لديه حالة من الانغلاق والكمون ثتأصل معها مظاهر الحزن واليأس من هكذا مؤثرات ، فيقول (من الطويل) :

حَبِيبٌ إلِيهِ فِي نَصِيحَتِهِ رُشْدي

عَلَيَّ ، وَمَا زَالََتْْ مَوَدَّنُهَا عِندِي (rV)

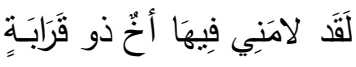

إذ وجد الثاعر (جميل بثينة) احدى ادوات الرفض والاستثناء عما يقال ، فكان حضور

(إلا) متمماً لآليات التحول التي استقدمها ليبين موققه للآخرين ، فالاسلوب كله قائم على كسر التوقع ، فبداية الثطر الاخير فيه عدول عن الاصل (ما انقصها الواشون) فاسهم بذلك في تحقق التناقض ، ثم تزداد حدة هذا التناقض بدخول اسلوب الاسنتناء ، وهذا الاسلوب هو احد آليات الصيرورة اللسانية التي تتصاع معها مظاهر الوعي الى منقابل ضدي مفارق يعرض عن مبتدأ الكلام الى ما بعده

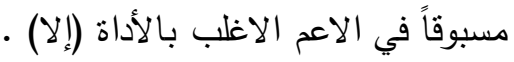
وفي خطاب الثاعر (قيس لبنى) نظهر بنية الاستثناء المفارق بالحرف (إلا) في قوله (من : (الطويل)

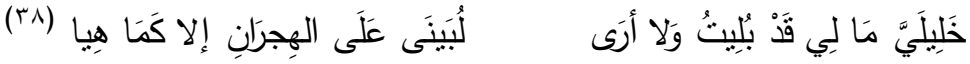
فالنداء محذوف الاداة مع الإحق من الخطاب الاستفهامي يجلي عن نمط من الارباك والتأزم بانت على محيا الثاعر ، وهو يتتبع حال مودوده ليجدها من دون المبالاة بالاعتبار لموضوع الاغتراب ، فحمول ذللك الظاهر على الآخر مع الضد من حال الثاعر ، استحضر مضمون الخطاب الاستفهامي ، كما ان جدلية المفارقة لم تخاطب طرفاً نداً هذه المرة بل اضحت في نقيض ملت مع الآخر القريب في بيان حاله المفارق مسبوقاً بلازمة الاستثناء (إلا) . وبالنداء المرخم يبدأ (جرير) خطابه المققى الذي يرتقع به عن الحاجة للحضور المفارق للكيان المادي المشخص لصورة الآخر الى ما تطلبه الروح من وجود معنوي يملأ ابعادها الوجودية ، التي ما تفتأ تلهج بالبكاء حينما تقتقه ، تلك الدلالة الروحية أثرت مضمون الخطاب المعتمد الذي سبق بالأداة (إلا) لاستثناء هذا الوازع المعد لتمثيل البعد الوجداني الحقيقي الذي يطلبه الناظم حينما قال (من الطويل) : 
العدد الحادي والأربعون

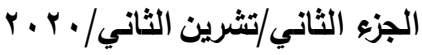

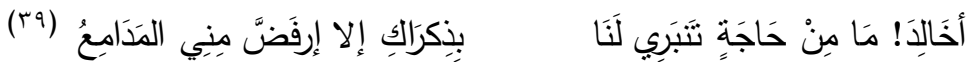

ونجد (ذي الرمة) قد استعان بأداة الاستثناء (غير) بدلاً من (إلا) ليكثف في ثنايا الخطاب الخاب

عن البعد الوجودي المتأصل في داخله تجاه الآخر فعد الى ترصين البنى الدلالية بتضمين النص بله المفارق لمعنى الاستثناء ، في قوله (من الطويل) :

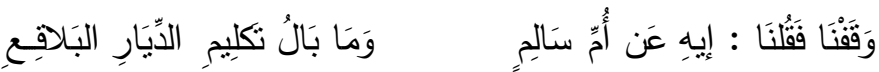

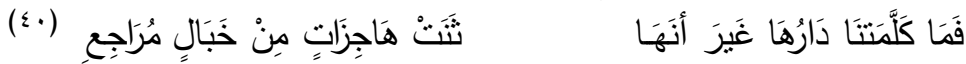

فتوجيه الاستثناء بالأداة (غير) نجده قد حقق الغرض في تدعيم المعنى المفارق وتوجيه دفة

الضرورة للمعنى اللاحق بالنفي ، وهي في ذلك عالجت النص معالجة الحرف (إلا) كونها (تشبه (إلا) في مخالفة ما قبلها لما بعدها في النفي والاثبات)((ا)" ـ فمن الطلل يستطق الشاعر الاخبار عن مودوده (ام سالم) ، ويأمل من بقايا حجارة الدار ان تبادله الاخبار عن ساكنيها ، ونلك الشطط النفسي والاسهاب في تفعيل قوة الخيال لهو من دواعي الضغط الروحي وتقل الهواجس التي المت بالثاعر بعد تصرم رهط الشريك ، وابتعادهم عن مسثقرهم ومثواهم ، فهي بالتأكيد مفارقة ذاتية باعدت بين شطري الواقع والخيال ضمن البنية الذهنية للناظم ، وجعلته رهين الوساوس والآمال . وكذلك يعمد الثاعر (كثير عزة) الى توظيف معطيات الاستثناء المفارق بالأداة (إلا) ،

كميزة اسلوبية استقدما مع اساليب الثرط والتشبيه لبيان وترسيم صورة سلبية عن الآخر المحايث لإله للشعور ، المتسم بمعطيات نفسية وسلوكية منفرة لأقرب متعالقيه ، وفي هذا النص تتكثف للقارئ الحذق تصورات مفارقة للتي حاول الثاعر اثباتها وتدعيمها ، كان الغرض منها اخماد نوازل المغرضين من الوشاة بإيهامهم بتلك التصورات السلبية عن الآخر التي دفعته الى جفائه ، فكل ما جاء بتلك الصور البيانية المدعمة بالمحسنات البلاغية كان القصد منه هو ابطال مكامن النسق بالن القهن المضاد ، بمفارقة آلياته المعتمدة الباثة لروابط المشاحنة والبغضاء بين سرابيل طرفي التعالق

$$
\text { الوجداني ، حينما قال (من الطويل) : }
$$

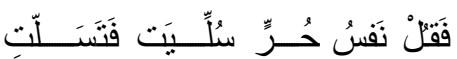

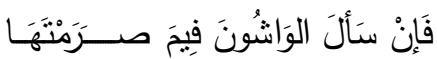

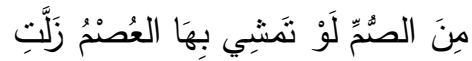

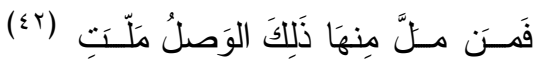

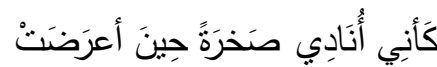

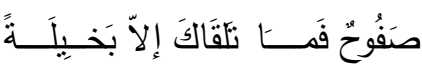

فالاستثناء بـ (إلا) جاء هنا لتدعيم واثبات ما قبله من اشكال التزامن المبغَض من السلوك ،

والذي فارق الناظم الظاهر منه بما اخفاه . 
العدد الحادي والأربعون

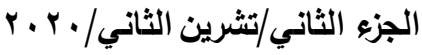

أما مجنون ليلى فقد استكان الى الاداة (سوى) كواصلة استثنائية اسست لحضور مبدأ

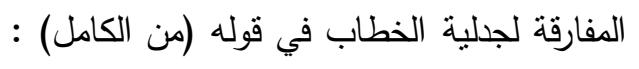

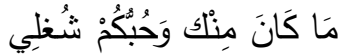

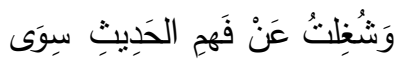

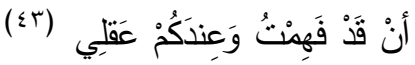

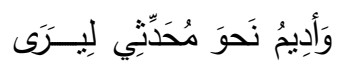

فبنية النص المققى جاءت مستوفية للمعنى الموضوع بما حوته من محمولات برهنت على ثبوت مظاهر الاستماع والفهم عند الشاعر باتصالها بطرف واحد من دون الاطراف الاخرى ، فكل ما يطرق اذنيه غير قابل للإدراك ، الا بما استثاه من عبارات شغفه ، المتسلط على ماهياته الحسية

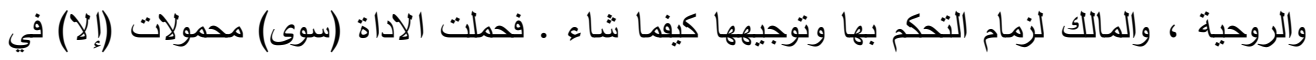
المستوى والنوع والعمل ، محققة صورة اخرى من صور الاستثناء المفارق .

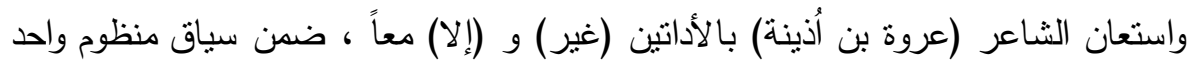

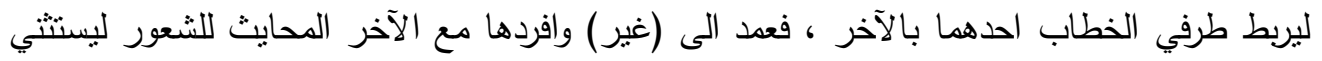

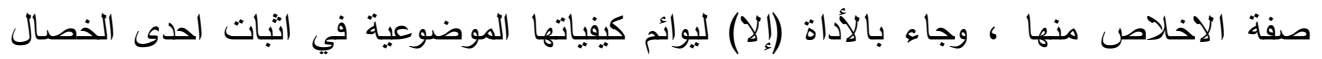
الحميدة الملازمة له وهي الكتمان ، فالاولى جاءت قيمة الاستثناء فيها موجهة بالنفي للأم والثانية جاءت في مقام الاستثناء بالإثبات للمدح ، وكل تللك المتعالقات المفارقة اناخت على على الإبعاد الدالالية صبغة جمالية اطرت حدود النظم بما منلكه من اتقان وتتسيق وتطريب في قوله (من الطويل) :

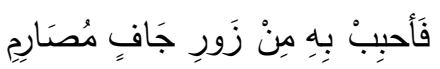

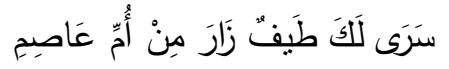

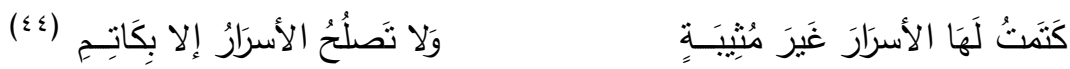

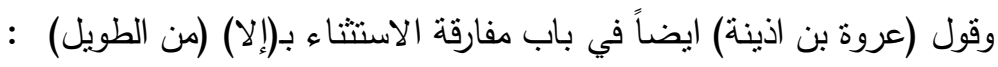

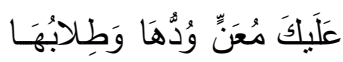

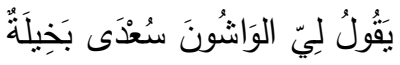

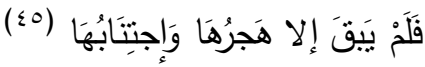

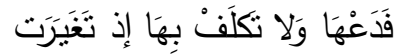

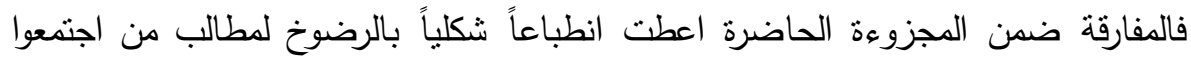

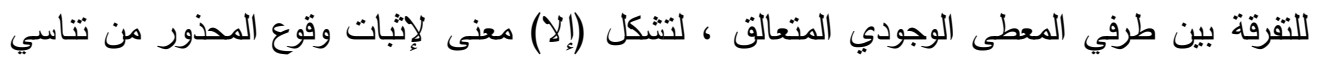
الآخر وتعتيم ذكراه وتجميد تصوراته ، وبعدها نستبين حقيقة الموقف الذي تبناه الناظم حينما قال (من الطويل) : (مثئ)

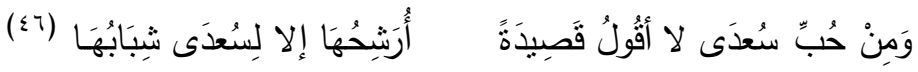


العدد الحادي والأربعون

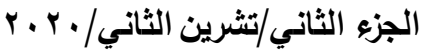

فجاءت (إلا) لإثبات وتذعيم موقف الثاعر فطبيعة الاستثناء مع ادواته تتضوي ضمن الاطر البيانية للصياغات الثعرية ، فهي معدة لتتلاقح مع محمولات الخطاب في حال النفي والاثبات ، وكما جاء في تعريف ابن مالك بانه ، اي الاستثناء ((المُخرج تحقيقاً أو تقديراً من مذكور

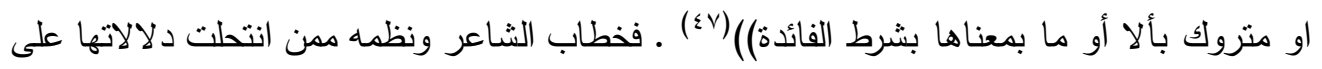
ميزات تحمل طابع الحيوية والبعد العاطفي هي ممن يلازم مقتضاها ومسارها الآخر (سُعَىى) .

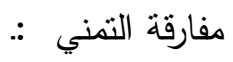
تشكل بنية التمني مفارقة في شعر الغزل ، بوصفها تحتضن معنى رغبة في الحصول على شيء يبدو مستحيلاً أو صعب تحققه ، إذ انه نوقع الأمر المحبوب الذي لا يرجى ولا ينوقع حصوله :

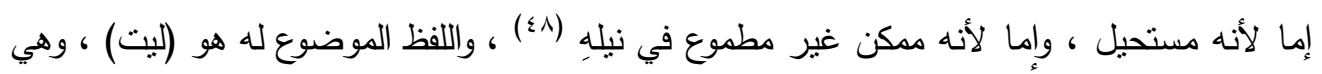
حرف مشبه بالفعل يختص بالاخول على الجملة الاسمية ، وتستعمل الادوات (هل ، لو ، لعل)

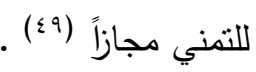
وهذا الاسلوب هو من جملة الاساليب البلاغية التي سجلت حضورها ضمن منظومات الشعر الغزلي ، بوصفه يشكل في كثير من الاحايين مطمحاً ترنو الى تحقيقه النفوس المتولهة ، بعدما تضنيها مكابدات الواقع وعراقيله ، التي تقف عائقاً في طريق تحقيق رغباتها المادية والروحية ، فيأتي التمني حينها كحل امنل يطلقه عنان خيال المتعالقين لإيجاد منفذ وهمي يكون عادةً بعيد المنال تتزاح معه كل مكابداتهم ، فيضحون معه في حلٍ من ايةِ رابطة اجتماعية او اخلاقية او دينية تقطع

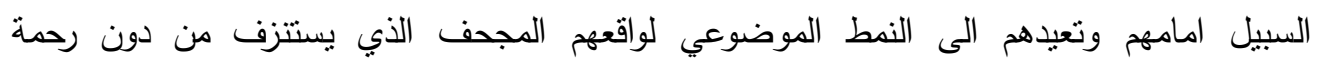

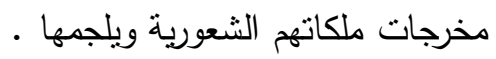
وقد تحقق حضور الأداة (ليت) بصورة واضحة كلفظة رئيسة في تشكيل بنية مفارقة التمني عند اغلب شعراء الغزل للعصر الاموي ، كما في قول (كثير عزة) (من الطويل) :

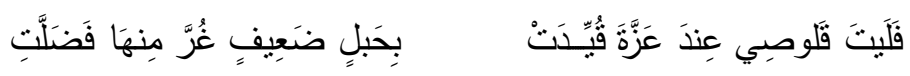

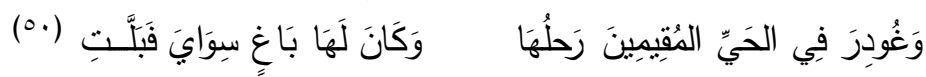
وموضوعة التمني تتحقق هنا بأبسط صورها بالنسبة للقارئ حينما يتعلق الأمر بقصد الثاعر ارخاء قيد راحلته حتى تستطيع الافلات والابتعاد الى ما لا يمكن معه ايجادها او رجوعها في بالي حين يسنطيع ملازمة موضعه والبقاء مع مودوده اطول فترة ممكنة ، بعد تحقق الحجة بانقطاع اسباب الرجوع ، والواقع ان بنية المفارقة هنا كان لها سببُ ذو قيمة للثاعر او الى العربي عموماً ، فالراحلة 
العدد الحادي والأربعون

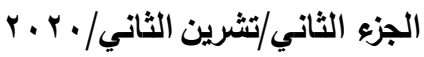

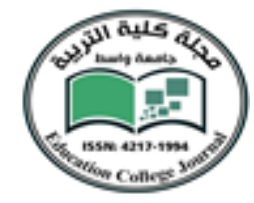

لا تقل اهيتها عنده عن اي لازمة اخرى من لوازم العيش والبقاء اذا لم تفوقها ، وبفقدها سيكون لها وقع ثقيل لا يجاريه الا فقد الشريك ، وفي هذه الحال تمنى الناظم التفريط براحلته كي يظفر بطول

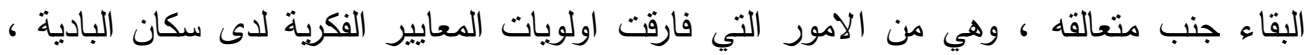
فتحقق المعنى بإبراز الأهمية التي يمثلها الآخر المحايث للشعور حينما اردفها بأداة التمني (ليت) .

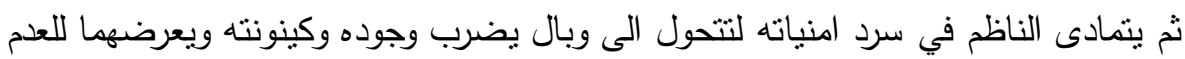

$$
\text { هو ومتعالقه ، إذ قال (من الطويل) : }
$$

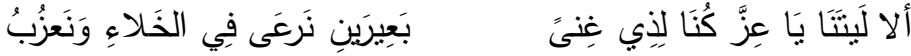

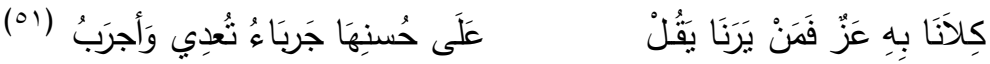

فهذا الاسلوب الثناذ من اساليب التمني يبين حالة الككون التي وصلت اليها تصورات الناظم حتى تتطلع الى مثل هكذا مصبر ، يستكين معه الى صورة بشعة من صور الوجود وهو دابه جرباء تهدد بالعدوى كل من يقترب منها ، حتى يصبوا الى تحقيق جو الصفاء بينه وبين متعالقه ، فيكون الناظم في هذه المجزوءة قد وصل الى اقصى درجات اليأس من كينونته الانسانية ، واضحت ابياته

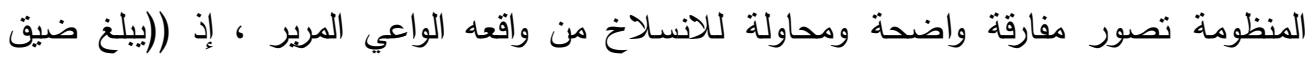

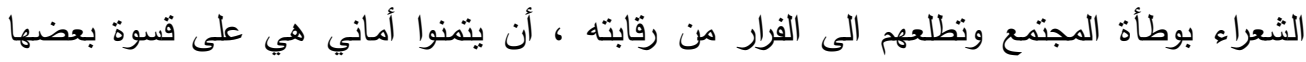

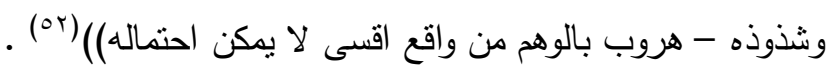
وفي نص آخر نلحظ تحقق حالة التمني لاسترجاع ما تصرم من محدوث الزمان على امل ان تتسال بوادر الامتاع من جديد برفقة الثريك ، الذي ترنو اليه الروح كحنو المولود لصدر امه اله فحالة التزقب لإعادة ما مضى لم تقتصر على إبصار العانقين وبعد امانيهم ضمن زمان ومكان

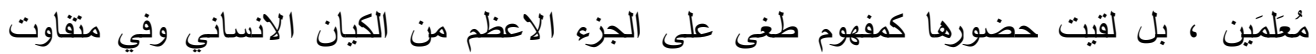
الازمان والبقاع ، ويتركز هذا الدفهوم على تمني تخطي صيرورة الوجود وامكان رجوعها القهقري ، ليجد الكائن لذاته صفحاته المتتاثرة على سلم الزمان ، فيلمل اشتاته ، ويجانب تاريخه وتراثه ، ويعيد

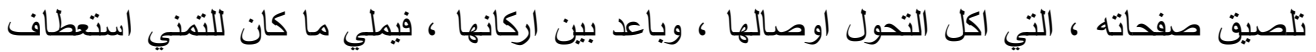
حدوثه ، حتى يكون للمرغوب برهانه وجوده ، وتلك امانيهم ، فهي بالنتيجة تبقى مطامح تثتاقلها الثفاه ، ولا تجد لها على ارض الواقع من اتكاء ، وضمن المعنى المتتاقل يقول (قيس لبنى) (من لئه 
العدد الحادي والأربعون

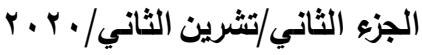

جامسـعة واســط

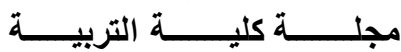

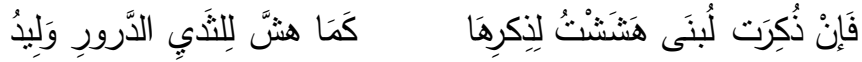

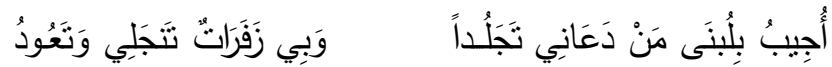

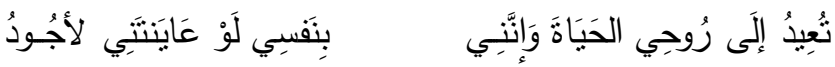

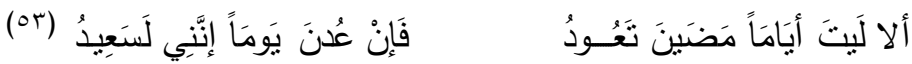

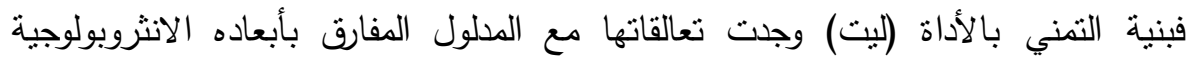

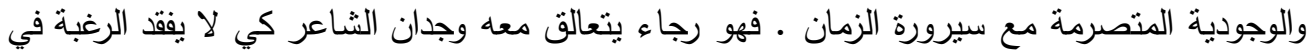

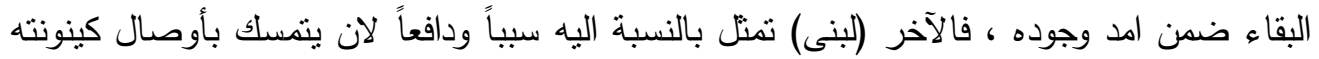

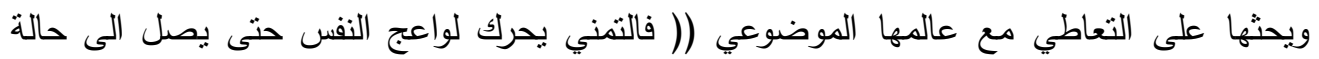

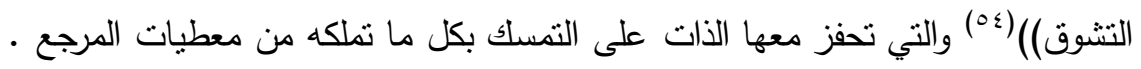
وفي ابعاد مفارقة اخرى بصيغة التمني يستهل (مجنون ليلى) مقطوعته المقفاة ، لينقل لنا صورة دفاعية مشبوبة بسلوك معتم ، يستميت في الصد فيها عن مودوده بالضد ممن بلمزونه ، فنتبري لنا مجادلة تستوقف معها اهمية هذا الكيان بالنسبة للناظم ، وتغظله في عمق كينونته ، وانقطاع السبيل الدقرون بالوعي من تزعزع صورة ذللك الآخر او انزياحها عن معطاه الوجودي المتأصل في جوهره ، فجرد كل مظاهر القبح اذا كان لها وجود في ذات الآخر من ان تخلع عن ذلك الك الكيان جلابيب التمايز والبهاء ، وهكذا فهو متنقن من قيمة ما احتازه الثريك وما احتواه من ضرورات مادية وروحية ازاء ضحالة تصورات الآخرين وتجاوزاتهم حينما قال (من الطويل) :

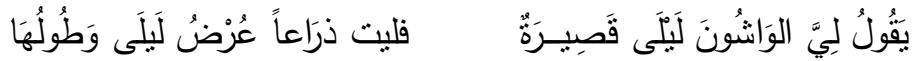

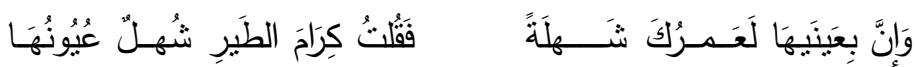

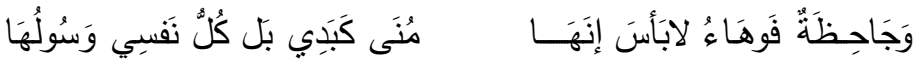

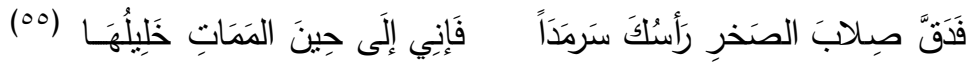
فبنية التمني ارخت بمظاهر الثعرية على الابيات الحاضرة بوصفها نقلت قيمة عليا للتحول الواعي بأبعاده الانسانية المفارقة ، وعالقت بين ندي الوجود (الجمال والقبح) ضمن جلئ الابت الخطاب

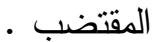
أما النتظي النفسي والروحي الذي خيم على جميع المفاصل اليقينية لوجود الناظم (جميل

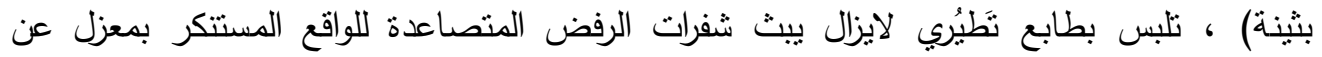
الثريك ، فهو لا يتمنى الا كما يتمنى لمودوده ، ولا يستكين في راحة على امتداد زمانه الحضوري لئي

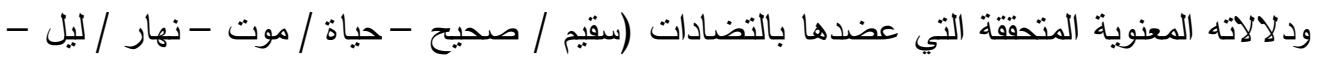


العدد الحادي والأربعون

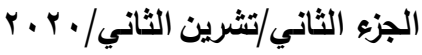

كتمان/ بوح) ، إلا وسرادق نفسه تتوثب صعوداً بلا هوادة مستلة كيانه عن وجوده وباعثة مكامن

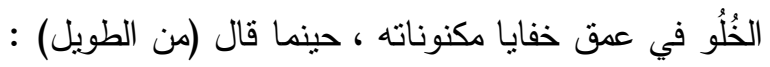

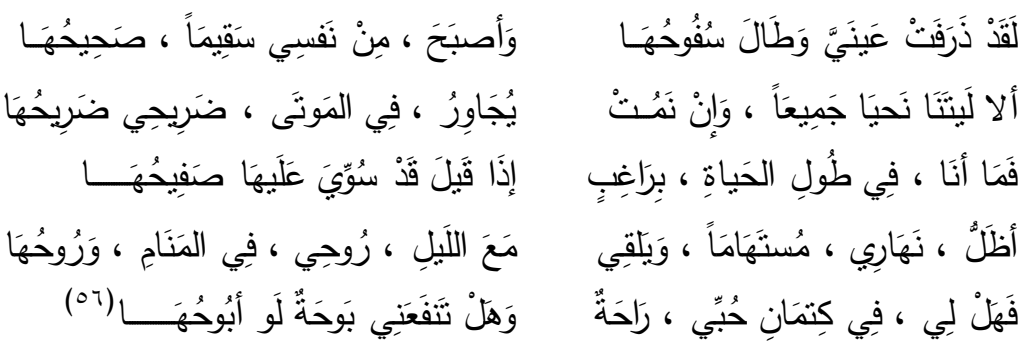
فالتمني بالأداة (ليت) هنا جاء ضمن منظومة مفارقة بُنت فيها محاور التضاد المرددة على في اكثر من نسق منقابل ، ليعمق فحوى الخطاب المتعالق في مجمل دواله بالآخر المحايث للشعور ، ولينقل صورة مميزة عن غور الاواصر الشعورية التي تسيدت ميول الناظم واستلبت بنى الارادة لديه ، فاصبح تابعاً يتمنى ان يجد له مكاناً مع الشريك ازاء مفارقات الكينونة والعدم. كما تتجلى تلك التبعية بصدورتها القاتمة عند الثاعر نفسه حينما نتركه مسلوب الارادة فاقداً

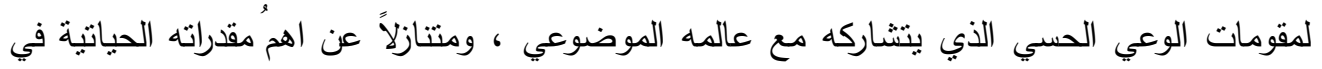
سبيل تحقيق ودوام حالة التلازم والتلاصق مع الآخر ، حتى لا يكون لوجود الناظم اي قيمة عملية ومعنوية دون ملازمة الثريك وتحكمه بإدارة وقيادة ماهياته التواصلية مع الواقع ، لفقانه مدركاته

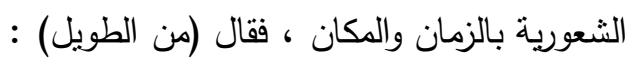
ألا لَينَتِي أعمَى أصَنمُ تَقُودَنِي

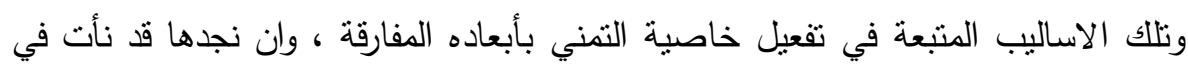

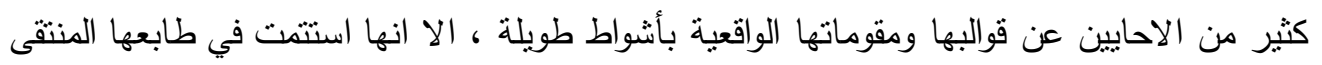
ابعاد وتمثنلات مظاهر الثعرية ، التي حققت حضورها المتميز في نُظم الغزل للعصر الاموي . ويطالعنا ضمن موضوعة مفارقة التمني قول الثاعر (عمر بن ابي ربيعة) (من البسيط):

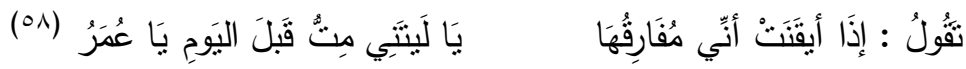
وفيه يعند الثاعر هذه المرة بخطاب الآخر الذي طبعت في محياه مظاهر التوله المقابلة لما الزمها الناظم نفسه ، فينقل لنا صورة الخطاب المقابل وردة الفعل المأساوية التي تأبى إلا ان تلازم محورها المحايث للثعور ، وتلك الملازمة اضحت من مقومات صور العاشقين ممن اضنتهم اللواعج وتيمهم الجوى واسقتهم منلبة الفراق ، فلم يعد لهم بد من الستلوَة ومبلغ لازم ، حتى لا يكون لهم بعد مند 
العدد الحادي والأربعون

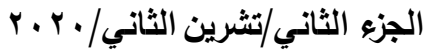

صبوتهم بقاء ، فلا يملكون اسباباً للعيش بعد نزول البلاء ، فمصيرهم مرهون بعد الثقاق بالقضاء ، ولكن الصورة المفارقة بعد اداة التمني (ليت) جاءت لتؤشر مضاني جديدة تتكابدها من تتمحور حولها في كل مرة مراكز الخطاب في نُظم الغزل وهي المرأة المستهام بها ، فأصبحت هي من نرقب نزول النوائل بعد الثقاق ، وبخطاب ذي ابعاد وتتاصات قرآنية صور لنا محنة سيدتتا العذراء في اثثاء

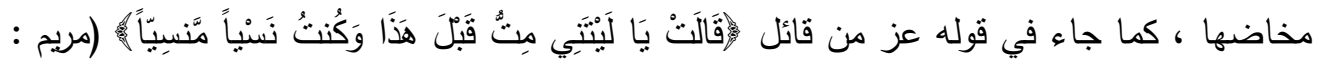

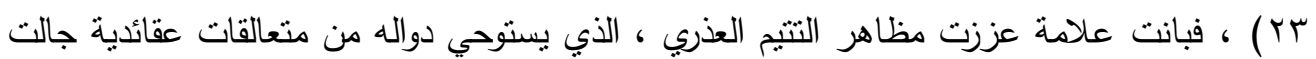
في تعزيز قوة الرابطة النقية التي جمعت بين لُبابهم مظاهر الجوى . فمعيار المفارقة اللغوية بان في النص الحاضر على شقين ، الاول في التحول الدلالي بعد لهد الاداة (ليت) ، وما يستتبع هذه الاداة من ترجيح للالالة اللاحقة لها على السابقة ، والثاني هو تبادل الادوار الذي تحولت فيه اقطاب التوله فاستتبعت مضاني وخواطر المستهام بها خلجات المستهام .

\section{الخاتمة}

تجلت إثز دراسة البنى التركيبية المفارقة في شعر الغزل الاموي ضمن مستويات الاضراب والاستثناء والنفي جملة من النتائج التي خلص اليها البحث في صيغته المنهجية الحاضرة والتي يمكن

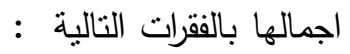

- المفارقة في مستواها التركيبي عند شعراء الغزل سلكت مسلكاً اعم مما بظهر في مستويات الطباق والمقابلة بتجاوزها مستوى المفردات والصيغ الى مستوى تراكيب كلامية مفارقة يتمخض النص

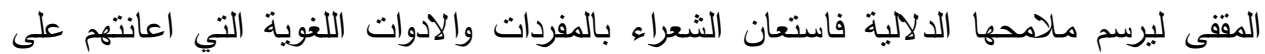
اخراج كيفياتها الابداعية من القوة الى الفعل . - استعان شعراء الغزل في العصر الاموي بمفارقة الاضراب من خلال ادخال البعض من ادواتها ضمن نظمهم مثل (لكن ، بل ، ام المنقطعة) كممارسة تحولية وكباب من ابواب التقاعلات الداخل نصوصية لترجيح القيم الجدلية للمعطى الدلالي لتتوافق مع منطلبات النظم المنفلت من القيود اللغوية بنسقها المعجمي المنغلق فحادت عن المسار المحدد لها سلفاً بما فرضته مجريات اللغة ولوازمها محيلة النص الى مسار جديد ترجح معه خصيصة الاحتمال - ـلبست انساق المفارقة في مفهوم الاستثناء عند شعراء الغزل الاموي طابعاً انتقائياً استتبطت فيه احداثيات التحول الالالي مجراها المحد من خلال استغلالهم للأدوات المحققة لذلك المفهوم ، 
العدد الحادي والأربعون

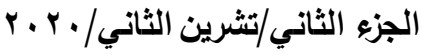

وهي (إلا ، غير ، سوى) ، التي انسلخ معها المضمون القبلي عن البعدي وباستقراء اساليب الاستثناء عند هؤلاء الثعراء وتنوعاتها افرزنا النمط البنائي القابع وراء التمثلات الكيفية لأوجه تحقهه في الخطاب الغزلي وصيرورته ضمن حدوده المعطاة عبر متضايفاته من الادوات المذكورة التي تحققت بحضورها وتفعيلها ضمن النظم الغزلي مخرجات صور الاستنثاء بطابعها المميز • - سجل اسلوب التمني بالأداة (ليت) حضوره الملفت ضمن الاساليب البلاغية التي وظفها شعراء الغزل في منظوماتهم الشعرية ، بوصفه شكل مطهاً طالما ارادت النفوس التي اضناها الثوق من نيل نوازعه واستمكان موارده ، فمظاهر التمني كانت بمثابة حل امثل بطلقه عنان خيال المتعالقين لخلق عالم وهمي يكون عادةً بعيد المنال نتزاح معه كل مكابداتهم ، فيضحون معه في هي حلٍ دن ايةِ رابطة اجتماعية او اخلاقية او دينية تقطع السبيل امامهم وتعبدهم الى النمط الموضوعي لواقعهم المجحف الذي يستنزف من دون رحمة مخرجات ملكاتهم الشعورية ويوئدها .

\section{الهوامش}

(") الهيولي : كلمة يونانية نزجع الى فلسفة ارسطو ، براد بها المادة الاولى التي انحرت منها الموجودات ، فهي نقبل

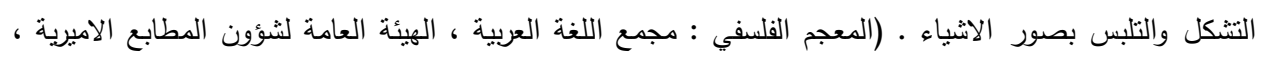

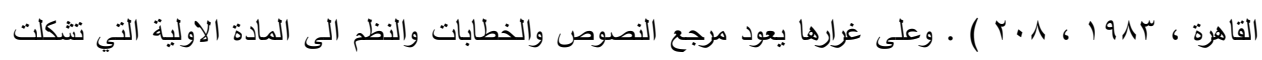

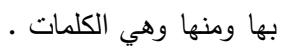
("** اساليب الكلام : وهي تحليل العلاقة القائمة في مدلول الكلام بين المتكلم والمستمع ، او المعاني التي تواضع الناس

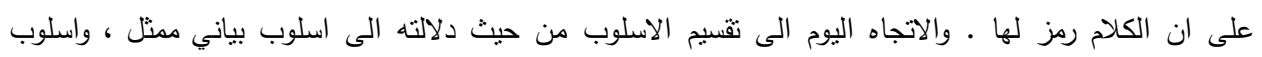

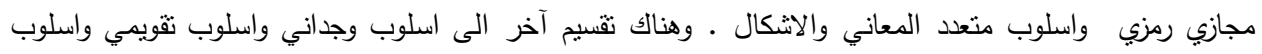

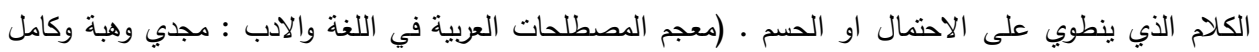

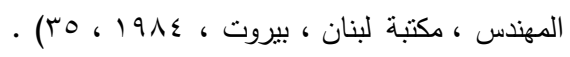

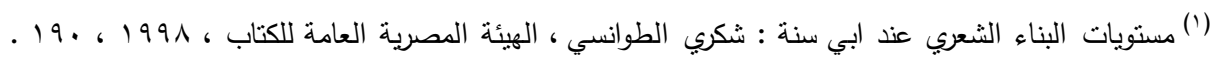

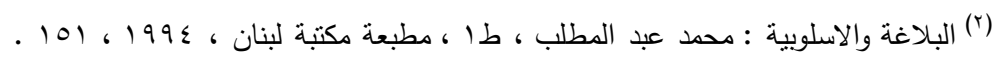

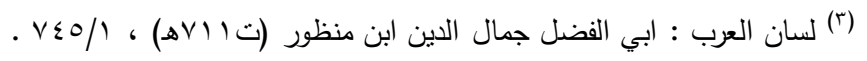

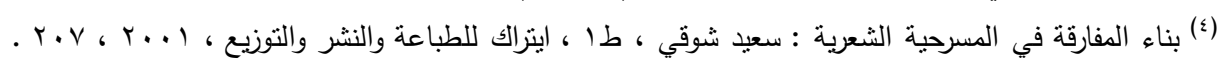

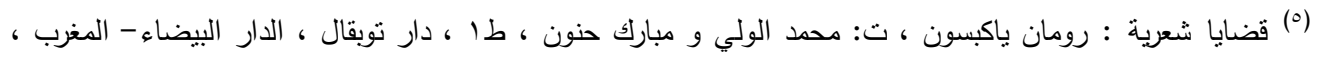


العدد الحادي والأربعون

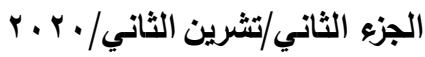

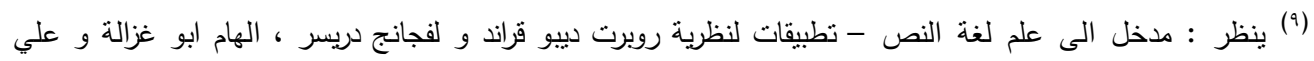

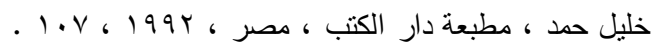

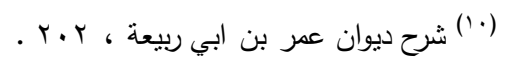

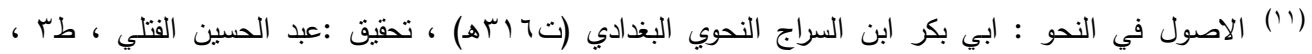

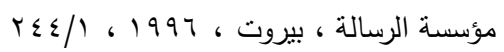

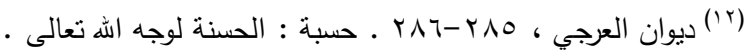

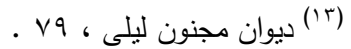
. $1 \leq$ ، 1 م.

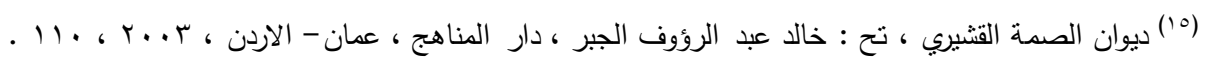

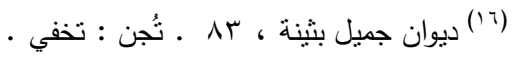

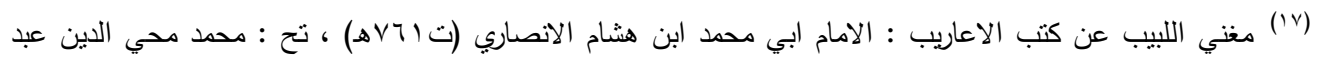

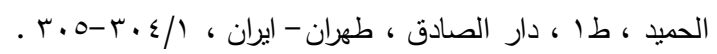

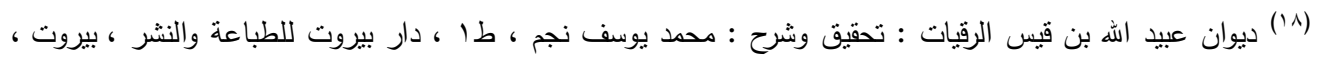
. 94 1901

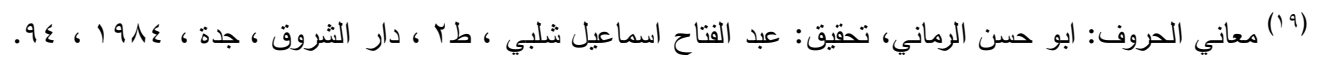

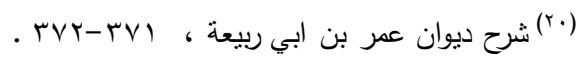

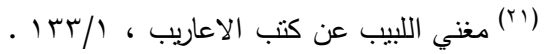

$$
\begin{aligned}
& \text {. }
\end{aligned}
$$

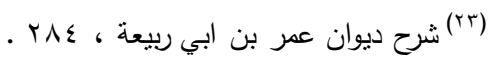

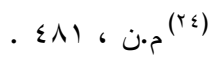

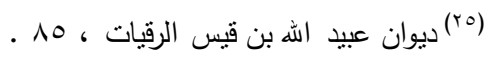

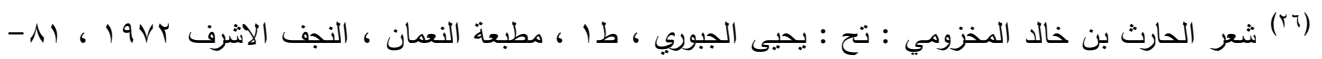

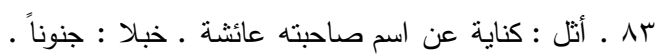

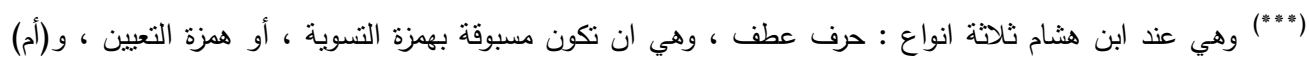

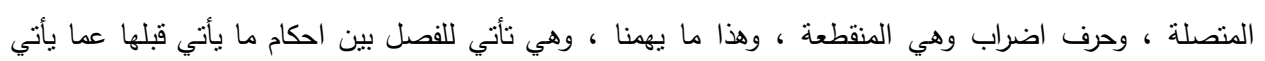

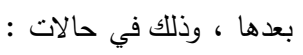

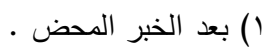

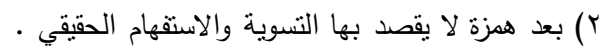

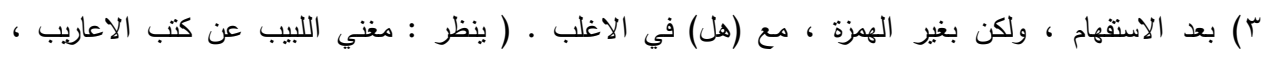

$$
\begin{aligned}
& \text {. (7人-7r/) }
\end{aligned}
$$

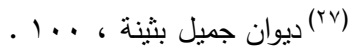

$$
\begin{aligned}
& \text { (Y^) }
\end{aligned}
$$




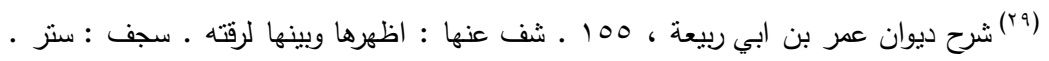

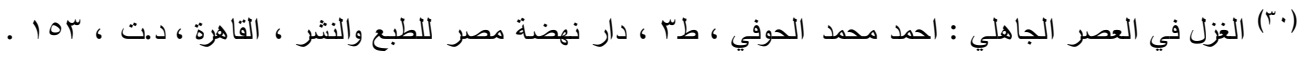

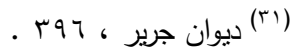

$$
\begin{aligned}
& \text { (r) } \\
& \text { ( ) }
\end{aligned}
$$

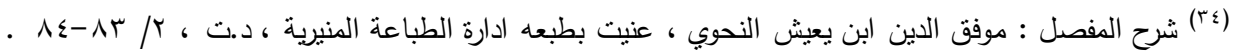

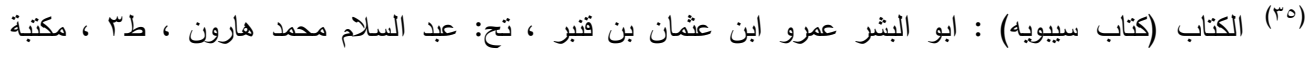

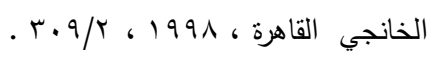

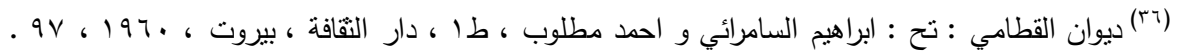

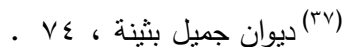

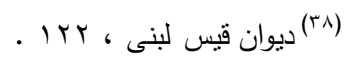

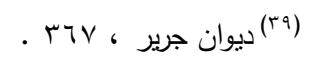

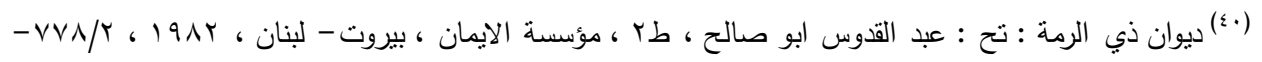

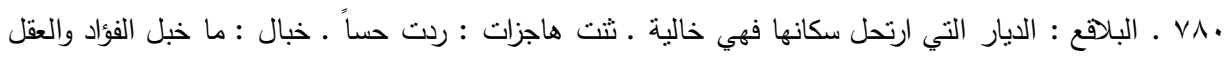

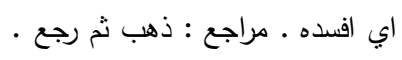

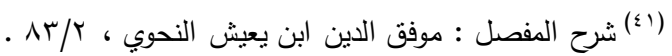

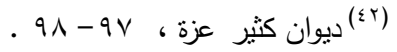

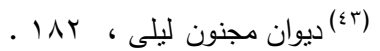

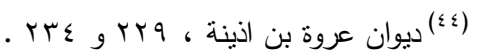

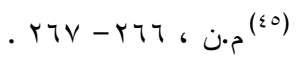

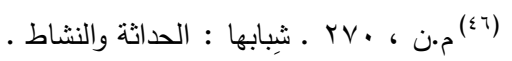

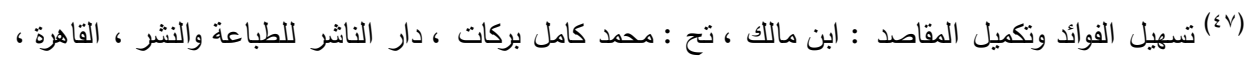

.1 .1 197V

(^)

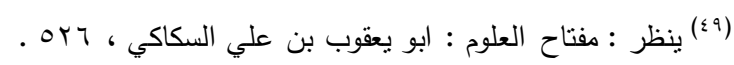

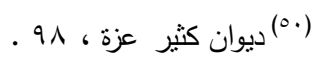

$$
\text { . } 171 \text { ، } 17 . \mathrm{r}^{(01)}
$$

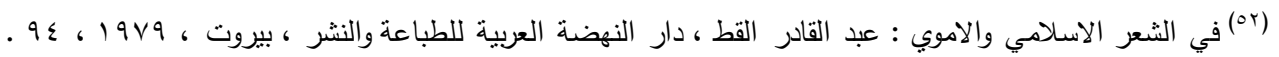

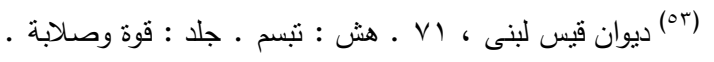

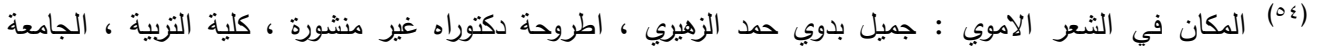

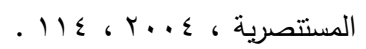

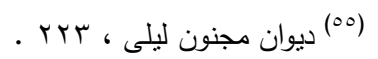


العدد الحادي والأربعون

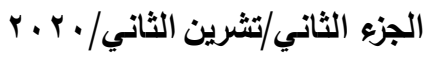

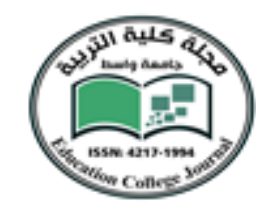

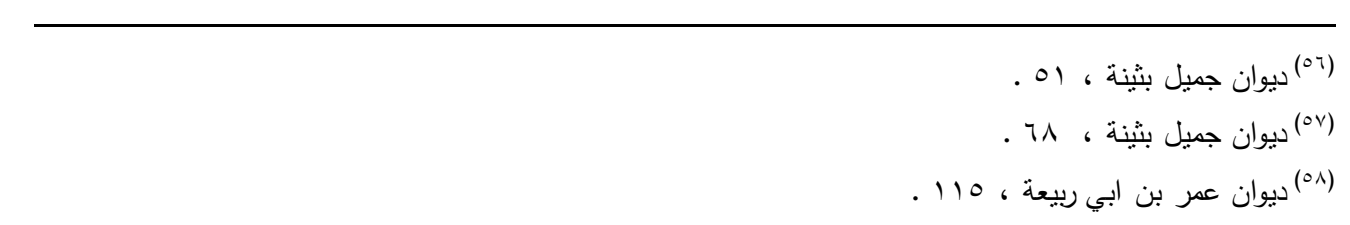

المصادر والمراجع

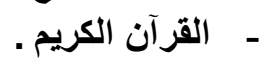

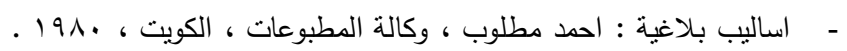

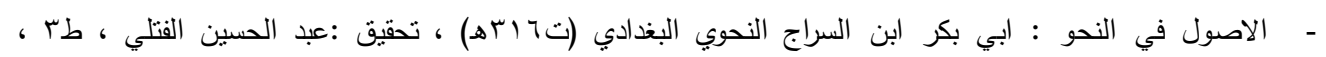

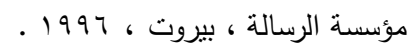

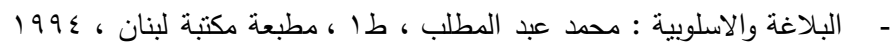

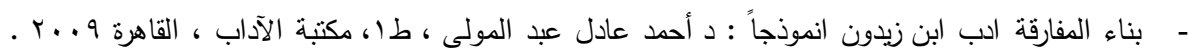

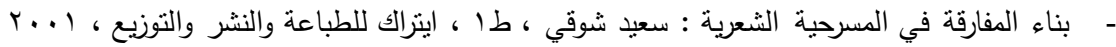
- تسهيل الفوائد وتكميل المقاصد : ابن مالك ، تح : محمد كامل بركات ، دار الناشر للطباعة والنشر ، القاهرة ، . $197 \mathrm{~V}$

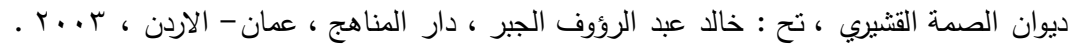

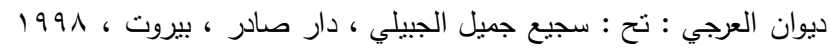

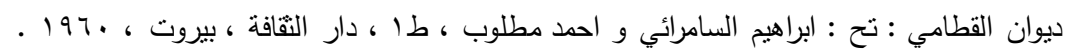

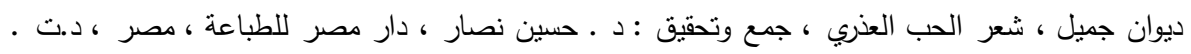

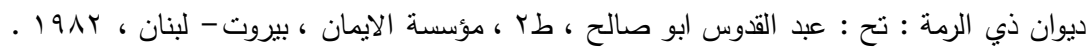

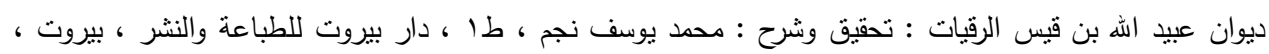
. 1901

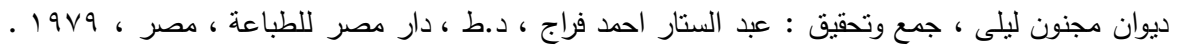

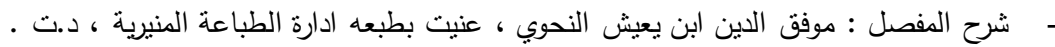

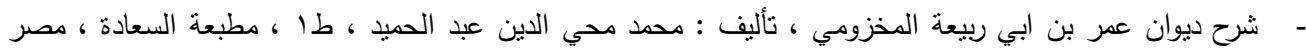
.190r.

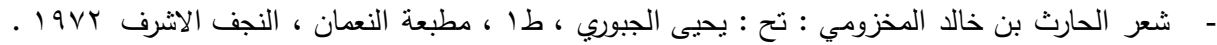

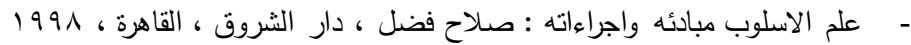

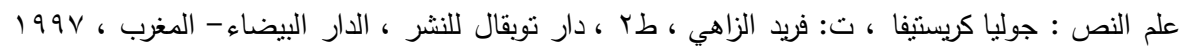

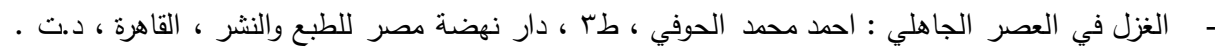

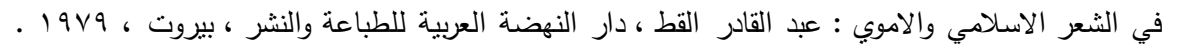

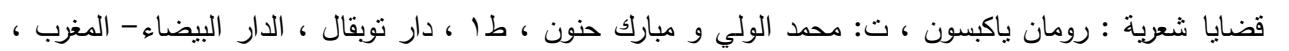


العدد الحادي والأربعون

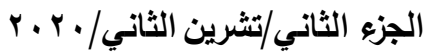

- الكتاب (كتاب سييويد) : ابو البشر عمرو ابن عثمان بن قنبر ، تح: عبد السلام محمد هارون ، طب ، مكتبة

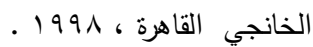

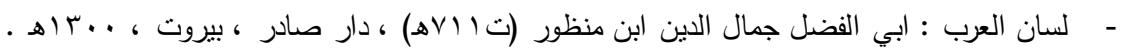

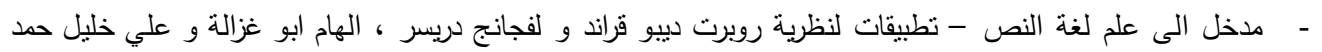

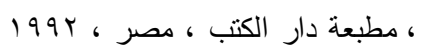

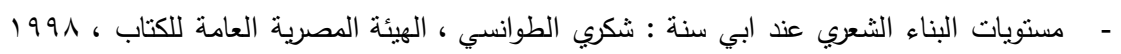

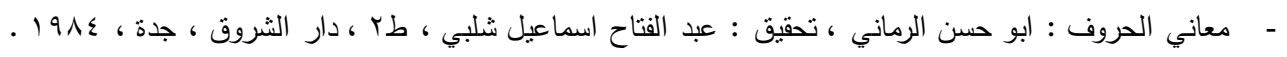

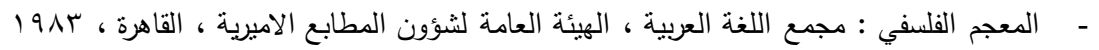

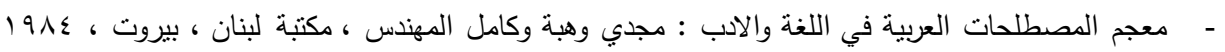

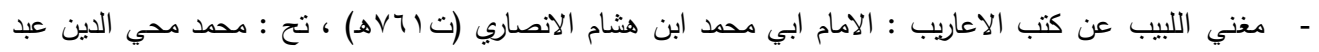

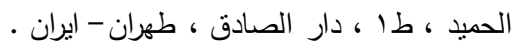

- المكان في الثعر الاموي : جميل بدوي حمد الزهيري ، اطروحة دكتوراه غير منشورة ، كلية التربية ، الجامعة

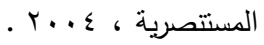

